\title{
Örgütsel Yabancılaşmanın Yordayıcısı Olarak Farklılıkların Yönetimi'
}

\author{
Ali ÇELIK* \\ Sultan Bilge KESKINKILIÇ KARA**
}

\begin{abstract}
Öz: Bu araştırmanın amacı, eğitim kurumlarında farklılıkların yönetiminin örgütsel yabancılaşmaya etkisini incelemektir. Araştırma nicel araştırma yöntemlerinden yordayıcı ilişkisel tarama türünde desenlenmiştir. Araştırmanın, evrenini İstanbul ili Sultangazi ilçesinde kamuya bağlı okullarda görev yapan 3521 öğretmen, örneklemini ise Sultangazi ilçesinde okul türüne ve okul büyüklüğüne göre belirlenen okullardan 371 öğretmen oluşturmaktadır. Verilerin toplanmasında 'İşe Yabancılaşma Ölçeği' ile 'Farklılıkların Yönetimi Ölçeği' ve demografik bilgi formu kullanılmıştır. Verilerin analizinde tanımlayıcı istatistiksel yöntemler olarak frekans, yüzde, aritmetik ortalama ve standart sapma kullanılmıştır. Araştırmada değişkenler arasındaki ilişkiyi belirlemek amacıyla Pearson korelasyon analizinden bağımlı değişkenin bağımsız değişkeni yordama düzeyini belirlemek için ise regresyon analizinden yararlanılmıştır. Araştırma sonucunda, farklılıkların yönetiminin örgütsel yabancılaşmanın yordayıcısı olduğu tespit edilmiştir. Farklılıkların yönetiminin yönetsel uygulamalar ve politikalar ile bireysel tutum ve davranışlar boyutlarının güçsüzlük, anlamsızlık, yalıtılmışlık ve okula yabancılaşma biçimindeki örgütsel yabancılaşma düzeyinin anlamlı birer yordayıcısı olduğu ancak örgütsel değerler ve normların güçsüzlük, anlamsızlık, yalıtılmışlık ve okula yabancılaşma düzeyinin anlamlı bir yordayıcısı olmadığı belirlenmiştir.
\end{abstract}

Anahtar Sözcükler: Farklılık, Farklılıkların Yönetimi, Yabancılaşma, Örgütsel Yabancılaşma

\section{Diversity Management as a Predictor of Organizational Alienation}

\begin{abstract}
The purpose of the study is to examine the impact of diversity management on organizational alienation in educational institutions. The research is in the correlational model. There are 3521 teachers for the schools in Sultangazi District in Istanbul. The sample of the study consists of 371 teachers in Sultangazi district, which is determined by the type of school and school size. To collect data 'Work Alienation Scale', 'Diversity Management Scale' and the information form consisting of demographic characteristics were used. Frequency, percentage, arithmetic mean and standard deviation were used as descriptive statistical methods. In order to determine the relationship between variables, regression analysis was used to determine the relationship between independent variables. As a result of the study, it was determined that the diversity management is the predictor of organizational alienation. It was also determined that the dimensions of managerial practices and policies and individual attitudes and behaviors of diversity management were significant predictors of the level of organizational alienation in terms of weakness, meaninglessness, isolation, and alienation of school.
\end{abstract}

Keywords: Diversity, Diversity Management, Alienation, Organizational Alienation

${ }^{1}$ Bu makale birinci yazarın yüksek lisans tezinden türetilmiştir.

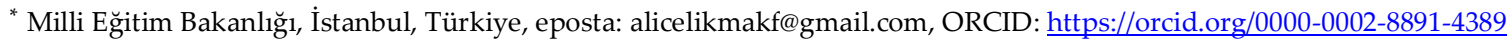

** İstanbul Kültür Üniversitesi, Eğitim Bilimleri Fakültesi, Rehberlik ve Psikolojik Danışmanlık Bölümü, İstanbul, Türkiye, eposta: s.kara@iku.edu.tr, ORCID: https://orcid.org/0000-0003-1951-7838 


\section{Farklı1ıkların Yönetimi ve Örgütsel Yabancılaşma}

Büyük bir ormanda bulunan bitkiler gibi, bireyler de farklı şekil, boyut, ölçü ve renkte özelliklere sahip olarak dünyaya gelirler. Bu farklılık bireyleri birbirlerinden ayırt etmeye yaramaktadır. Bireyler aynı türden olan fakat özelde birçok özelliği ile bir diğerinden farklılaşan canlılardır. Yıllarca bireylerden hem toplumda hem de örgütlerde; aynı şekilde düşünen, aynı şekilde davranan ve hatta aynı şekilde giyinen insanlar olmaları istenmiştir. Ancak hiçbir baskı, düşünce veya eylem farklılıkların var olduğu gerçeğini değiştirememiştir (Okat, 2010, s.7). Yaşamın bütün alanlarında var olan bireysel farklılıklar, insanların kurduğu ve oluşturduğu örgütsel yaşam içinde de oldukça önemli bir olgu olarak karşımıza çıkmaktadır. Çünkü örgütün işgörenleri arasındaki uyum ve ahenk, örgütsel çıktılar açısından oldukça etkili olmaktadır. Aynı örgütsel hedeflere ulaşmak amacıyla bir araya gelen bireyler, hem öteki işgörenlere ve örgütsel işleyişe uyum sağlamaya gayret ederken hem de kendi özünde bulunan farklılıklarından (cinsiyet, yaş, engellilik vb.) dolayı herhangi bir kısıtlamaya maruz kalmadan yaşamak ve bu farklılıklarına karşı saygılı olunmasını istemektedirler (Sürgevil ve Budak, 2008).

Türk Dil Kurumu sözlüğünde farklılık kavramı, "Farklı olma durumu, ayrımlılık, başkalık” biçiminde ifade edilmektedir. Türk Dil Kurumu sözlügünde, felsefe alanında farklılık; "Doğal, toplumsal ve bilince dayanan her olay ve olguyu bütün ötekilerden ayıran özellik" biçiminde tanımlanmaktadır (Türk Dil Kurumu [TDK], 2018). Barutçugil (2004, s. 227) farklılığı, bireylerin kişilik özelliklerini, çalışma stillerini, bedensel özelliklerini, din, milliyet, cinsiyet, eğitim ve bireysel deneyim ve tecrübelerine kadar pek çok özelliği kapsayan bir kavram olarak tanımlamaktadır. Farklılık, farklı toplumsal kimliklerinden dolayı başkalarını benzer ya da benzer olmayan şeklinde sınıflandıran grup üyeleri tarafından yaratılmış öznel bir olgudur (Mazur, 2010, s. 5-6). Sürgevil (2010, s.10) ise, farklılıkları demografik özellikler; çalışma hayatı ile ilgili bilgi ve beceriler; değerler, inançlar ve davranışlar; kişilik, zihinsel ve edimsel stiller; örgütteki konum ve benzeri niteliklerin tümü olarak ifade etmiştir.

İş hayatında, işgücünü oluşturan bireyler arasında görülen tüm farklılıklar, kişisel özellikler olmakla birlikte, yönetilmesi gereken bir olgu olarak karşımıza çıkmaktadır. Farklılıkların etkili bir biçimde yönetilebilmesiyle bütün işgörenleri içine alan bir örgüt kültürü oluşturulması, çoğu kez örgütlerin ve örgüt yöneticilerinin ahlaki ve toplumsal sorumluluk gibi endişelerini gidermekte; birçok kez de örgüt performansını, karlılı̆̆ını ve verimliliğini artırmaktadır (Sürgevil, 2008, s.1).

Farklılıkların yönetimi, bütün çalışanları içeren, tüm işgörenlere eşit olanaklar oluşturmakla birlikte, çalışanların farklılıklarına saygı duymayı ve farklılıkların, bireysel ve örgütsel amaçların gerçekleşmesi için değerlendirmeyi temel almaktadır. Örgütsel açıdan bu farklılıkların yönetime yansımasının, meydana getireceği fayda ve zararların bilinmesi önemlidir. Bundan dolayı son yıllarda işgücü farklılı̆̆ı, birçok örgütün en önde ilgilendiği konulardan biri olmuş ve farklılıkların anlaşılması, günümüzde yöneticiler için bir gereklilik haline dönüşmüştür. Artık yöneticiler örgüte sağlayacağı yararları fark edip, işgörenlerinin ne kadar farklı yetenekleri varsa onları değerlendirmeye ve bu farklılıklardan faydalanmayı benimsemektedirler (Çako, 2012, s. 6).

Farklılıkların yönetimi, insan farklılıklarının olduğu gibi kabul edilmesini benimseyen bir yönetim şekli olarak örgütlerde hiçbir kişi ve gruba ayrıcalık yapılmamasını temel ilke kabul ederek; bütün farklılıkların, bireysel ve örgütsel amaçların gerçekleşmesi için yararlanılmasını hedeflemektedir. Bu bağlamda farklılıkların yönetimi, örgütteki bütün işgörenlerin yeteneklerini ve becerilerini ortaya çıkarabilmeyi hedefleyen kapsamlı bir yönetim anlayışıdır (Memduhoğlu, 2007, s. 4).

Farklılıkların yönetiminde temel amaç, birçok farklılıktan ortak bir noktaya ulaşabilmektir. Farklılıkların yönetimi, örgüt bünyesindeki işgörenlerin beceri ve yeteneklerinin örgütün amaçları ve çıarları doğrultusunda kullanılıp, çalışanların mevcut potansiyellerinin maksimum düzeye çıkarılarak çalışanların gerçek potansiyellerine ulaşmalarını temin edip örgüt amaçlarına ve çıkarlarına katkı sağlayacak şekilde örgüt atmosferi yaratma sürecidir (Gökçen ve Çavuş, 2014, s. 531).

Sürgevil'e (2008, s. 126) göre, farklılıkların yönetimi, işgörenler ve örgüt açısından bir gelişim unsuru ve 
örgütlerde üretimi, etkinliği, etkililiği arttırmak için etki gücü yüksek bir yönetim şeklidir. Farklılıkların yönetimi, ayrımcılık yapmadan tüm işgörenlere eşit fırsat ve çalışma koşulları sağlayan, örgüt içindeki işgörenlerin bütün farklılıklarına saygı duyan, değer veren ve bu farklılıklardan, örgüt performansını artıracak ve örgüte rekabetçi üstünlük sağlayacak şekilde yararlanılan yönetsel bir anlayıştır.

İşgörenlerin iş hayatına taşıdıkları farklılıklar örgüt açısından hem tehdit hem de zenginlik olma özelliği göstermektedir (Memduhoğlu ve Ayyürek, 2014, s. 176). Bu bağlamda farklılıkların yönetiminin iyi bir şekilde uygulandığı örgütlerde meydana getirdiği avantajlar bulunduğu gibi iyi yönetilemediğinde ise örgüt içinde oluşan olumsuzluklar söz konusudur.

Balay ve Sağlam (2004), farklılıkların yönetiminin yararlarını, yüksek yetenekli elemanları örgütte istihdam etmek, pazarın paylaşımında en iyi pozisyonu elde etmek, üst seviyede yaratıcılık, yeniliğe uyma, ilişkilerin çok kültürlüğe uyması ve yabancı müşteriye hassas olmak şeklinde ifade etmektedirler. Ayrıca kararların etkililiğinin artması, problemlerin çözülmesi ve örgütsel esnekliğin yardımıyla, işgörenlerin morallerini ve verimliliğini yükseltmesini de farklılıkların yönetiminin faydaların arasında belirmektedirler. Bunlarla beraber yönetsel süreçlerin kalitesini arttırarak, çevresel değişime daha kısa sürede ve daha hızlı uyum sağlayabilme, işten ayrılma, işe devamsızlık ve iş davalarına yönelik maliyetlerin azalması da farklılıkların yönetiminin yararlarındandır.

Farklılıkların yönetiminin, örgütsel bağlılığı azaltmak, iletişim sorunlarının ortaya çıkmasını sebep olmak, çatışma yaşanmasına neden olmak ve ayrımcılığı meşrulaştırma gibi örgütsel sakıncaları olabilmektedir. Örgütsel bağlılı̆̆ın azalması, iletişim problemlerin ortaya çıkması ve çatışma yaşanması örgütlerin işleyişinde ciddi şekilde sıkıntılar yaşanmasına neden olabilir.

İşyerindeki doyumsuzluklar, şikayetler, rol belirsizlikleri, iş güvenliği konusunda sıkıntılar, kariyer engelleri, keyfi ve özel davranışlar ve bunlara bağlı olarak gelişen düşmanlık-hırs duyguları gibi bir takım etmenler bireysel yabancılaşmanın yanında, örgütsel yabancılaşmaya da yol açmakta ve çalışanların örgüte karşı yabancılaşmalarına neden olabilmektedir (Gökçen ve Çavuş, 2014, s. 529).

Yabancılaşma bireyin insan olmaktan uzaklaşmasıdır. Bireyin insan olma halinden uzaklaşması ise kişinin insani değerlerini yitirmesi sonucunda kişilerin sosyal ilişkilerinde birbirlerinden kopması ve uzaklaşmasıdır. Bu bakımdan yabancılaşma, bireyin kendisinden, ürettiği üründen, yaşadığı doğal, toplumsal ve kültürel çevresinden uzaklaşmasına rağmen çevresinin kontrolünde hayatını devam ettirmesi olarak ifade edilebilir (Yilmaz ve Sarpkaya, 2009, s. 320).

Türk Dil Kurumu Sözlüğünde "yabancılaşmak” fiili; “Tanımaz, bilmez duruma gelmek, yabancı olmak, bigâne düşmek"; "Alışamamak, yadırgamak, yabancılık çekmek" kelimeleriyle tanımlanmaktadır (TDK, 2018). Marx (2013, s. 11) yabancılaşmayı bireyi, kendi faaliyetlerinin ürünlerine, üretkenliğin kendisine, içinde yaşadığı dünyaya, kendisine, insanlığına ve diğer bireylere yabancılaştıran fiiller olarak ifade etmektedir.

Fromm (2014, s. 125) yabancılaşmayı, kişinin dünyayı ve kendisini aktif ve etken şekilde değil de, diğer ifadeyle edilgen kabullenmesi hali olarak tanımlamaktadır. Yabancılaşma kişinin kendisini bir nesne olarak hissetmesi durumudur. Bu durumun nedeni de nesne ile öznenin birlikte oluşunun fark edilememesi, dünyanın bir bütünsellik içinde algılanamaması sonucu olarak ifade edilebilir. Tolan (1981, s. 92) ise yabancılaşmanın, bireyin makineleşmesine, metalaşmasına karşı bir isyan sembolü olarak da kullanıldığını ifade etmektedir. Bu özellikleriyle yabancılaşma hem sosyolojik hem psikolojik, hem de siyasal ve felsefi bir anlam taşımaktadır.

Seeman (1959), yabancılaşmanın tek bir tanımının yapılamayacağını, çünkü yabancılaşmanın ortaya çıkmasında hem toplumsal koşulların hem de duygusal kişiliğin etkili olduğunun ifade etmektedir. Bu duruma bağlı olarak yabancılaşmanın sosyo-psikolojik çerçevede çok boyutlu olarak ele alınmasının gerektiğini söylemektedir (Akt. Şirin, 2009, s. 165). Yabancılaşma çok boyutlu olarak irdelenebilir. İki grubun veya iki kişinin karşılıklı olarak birbirlerine yabancılaşabileceği gibi, bir birey de diğerine karşı yabancılaşabilir. Bu durumda yabancılaşmanın uzaktan veya platonik biçimde olabileceği gibi, karşı tarafa doğrudan düşmanca duygular şeklinde ortaya çıkabileceği söylenebilir (Minaslı, 2012, s. 49-50). 
Yabancılaşmayı felsefede ilk dillendiren Alman idealizminin öncüsü Hegel; sosyoloji alanyazınına kazandıran ise Karl Marx olmuştur. Hegel'in "dışsallama", Karl Marx'ın "yabancılaşma”, Durkheim'in "dayanışma", Weber'in ise "rasyonalizasyon" ile anlamaya ve anlamlandırmaya çalıştı̆̆ 1 yabancılaşma kavramı, daha çok Karl Marx'ın alanyazına kazandırdığı bir kavram olarak bilinmektedir (Çalışkan, 2015, s. 9).

Hegel, yabancılaşmayı bireyin gelişebilmesi için geçirmesi gereken bir evre olarak görmekte ve bireyin bireyselleşmesi şeklinde tanımlamaktadır (Ofluoğlu ve Büyükyılmaz, 2008, s. 120). Hegel'e göre yabancılaşmanın aşılabilmesi için, bu sürecin farkına varılması gerekmektedir (Demirer ve Özbudun, 1998, s. 12). Hegel felsefesinde yabancılaşma, mutlak ruhun kendisine dönmesi sürecidir. Hegel, yabancllaşmanın mecburi bir süreç ve kaçınılmaz bir durum olduğunun ifade etmektedir (Tolan, 2005, s. 285).

Feuerbach yabancılaşmayı; kişinin kendisini nesnelleştirerek tanrıyı yaratması ve yarattı̆̆ı tanrıyı ululaştırarak onun tutsağı haline gelmesi olarak ifade etmektedir. Feuerbach'a göre kişilerin yarattığı değerler ve düşünceler, yabancı ya da başka birinin ürünü olarak görülmeye başlanmakta ve bireyler kendi özünden uzaklaşmaktadır (Marx, 1993, s. 22-23). Feuerbach'a göre yabancılaşmanın tek pozitif yanı, bireyin benliğini dışarda araştırmasından sonra kendi içerisinde araştırmaya iten bir dönem ortaya çıkarmasıdır. Başka bir deyişle yabancılaşmaya neden olan din ve Tanrı imgesi, insana bir büyütme aynası görevi görmektedir (Demirer ve Özbudun, 1998, s. 16).

Marx, yabancılaşmayı ele almaya Hegel'i ve Feuerbach'ı eleştirerek başlamıştır. Hegel'i yabancılaşmayı nesnelleşme ile aynı gördüğü ve kişinin yabancılaşmasını bilincinin yabancılaşması şeklinde irdelediği için, Feuerbach'ı ise yabancılaşmayı sadece dinsel yabancılaşmaya indirgediği için eleştirmiştir. Marx, yabancılaşmayı düşünsel ve zihinsel yaklaşımdan kurtararak, yabancılaşmayı soyut olmayan, yaşanan ve sosyal gerçeklik içinde ele almıştır (Yılmaz ve Sarpkaya, 2009, s. 318).

Marx "1844 El Yazmaları" adlı eserinde, güncel iktisadi bir olgudan hareket ettiklerini ifade etmektedir. Marx'a göre, çalışan ne kadar fazla zenginlik üretir, ürettiği şeyler ne kadar fazla olursa, o kadar yoksullaşır. Ne kadar çok mal üretirse, o kadar ucuz bir mal haline dönüşür. Bireylerin, dünyasının kıymetsizleşmesi, nesnelerin dünyasının kıymetlenmesi ile doğru orantılıdır. Nesneler değerlendikçe insanlar değersizleşir. Emek yalnızca meta üretmekle kalmaz; meta ürettiği oranda, kendini ve çalışanı da alınıp satılan bir mal haline getirir. Böylece emek nesnelleşmekte ve emeğin nesneleşmesi, işçinin yoksunlaşması olarak görülmektedir. (Marx, 1993, s. 140).

Marx (1993, s. 141), işçinin kendi emek ürünü karşısındaki ilişkisinin, yabancı bir nesne karşısındaki ilişkisi ile aynı şekilde olduğunu ifade etmektedir. Marx'a göre emek, yabancılaşmanın önemli bir göstergesidir. Marx, yabancılaşmayı, emeğin çalışanın dışında olması, emeğinde çalışanın kendisini olumlamaması, mutsuz olması, çalışanın yaptığı işten dolayı vücuduna ve tenine zarar vermesi olgusuna dayandırır.

Marx, bireyin ancak güçlü mücadelelerle yabancılaşmadan kurtulabileceğini ve farklı biçimler alan bu mücadele için, kuramın gerekli ama işlevini tam olarak yapamayan bir araç olduğunu vurgulamaktadır. Marx'a göre yabancılaşma, yabancılaşmadan kurtulmanın kolaylıkla ve sahici imkânı ile ancak anlaşılabilir. Marx, yabancılaşmanın en kötü tarafının, gelişimi engellemesi olduğunu ifade ederek (Elma, 2003, s. 25) yabancılaşmanın değişik biçimlerde oluşabileceğini söylemiş ve kavramı dört boyutta irdelemiştir. Bu boyutlar; emeğe, iş sürecine, doğaya ve kendine yabancılaşmadır (Tolan, 1981, s. 145-152).

Seeman'a (1983) göre, yabancılaşmanın anlaşılmanı güçleştiren en önemli özelliği tek bir tanımının yapılamamasıdır. Seeman, yabancılaşma kavramının boyutlara ayrılmasının hem yabancılaşmanın anlaşılması hem de yabancılaşmanın ölçülebilmesi bakımından önemini ifade etmektedir (Akt. Tanrıverdi ve Kılıç, 2016, s. 3). Seeman, yabancılaşma kavramını sınırlandırarak kişiye tesirlerini basamaklar halinde ifade etmiştir. Seeman, yabancılaşmayı beş gruba ayırmıştır. Seeman'a göre kişinin kendisini algılaması ve davranışları bakımından oluşturulan kategoriler şunlardır; Güçsüzlük (Powerlessness), Anlamsızlık (Meaninglessness), Normsuzluk (Normlessness), Yalıtılmışlık (Isolation) ve Kendine Yabancılaşma (Selfestrangement). Seeman, yabancılaşmayı bu şekilde kavramlaştırmasının sebebini, yabancılaşmanın 
ölçülebilmesini kolaylaştırmak olarak ifade etmektedir (Şirin, 2009, s. 165).

Seeman güçsüzlügü̈, bireyin hayatını etkileyen şartlar üzerinde kontrol sağlayamaması, davranışlarının, beklentilerinden başka bir sonuç oluşturmak için yetersiz olduğunu düşünmesi ve bunun sonucunda yaşayışı ile ilgili olayların kontrolünü yitirmesi biçiminde tanımlamaktadır; anlamsızlığı, kişinin neyin doğru olduğunu kabul etmek konusunda gerektiği kadar bilgilenememesi ve kişisel karar alma durumunda kişinin doğru kabul ettikleri ile toplumun doğru kabul ettiklerinin aynı olmama hali olarak, kuralsızlığı koyulan hedeflere ulaşılabilmek için, kişinin toplumca kabul görmeyen tutum ve davranışları kabullenmesi olarak, yalıtılmışlığı toplumca çok önemli görülen norm ve amaçların insan için önemsiz ve değersiz hale gelmesi olarak tanımlamaktadır (Ofluoğlu ve Büyükyılmaz, 2008; Şirin, 2009; Tolan, 1996).

Örgütsel yabancılaşma, çalışanın çalışma hayatına karşı ilgisinin azalması ve çalışma heyecanın sönmesidir. Yabancılaşma yaşayan çalı̧̧an, çalışma hayatını sürdürse bile kendisini kurumun bir parçası olarak hissedemez. Yabancılaşma, görevle ilgili olduğu gibi bireyin ait olduğu gruba karşı da olması muhtemeldir. Yabancılaşmanın en kötüsü, çalışanın kendisine yabancılaşmasıdır. Yabancılaşma sonucunda ortaya çıkan kişinin işinden, kendisinden, etrafından uzaklaşması, kendisini zayıf hissetmesi, çalışma yaşamının anlamsızlaşması, kendi etkililiği ve örgütün amacı bakımından istenilen bir durum değildir (Başaran, 2000, s. 231).

Elma (2003, s. 16) örgütsel yabancılaşmanın nedenlerinin; işgörenin duyuşsal ve bilişsel ruh hali, işgörenin ürettiği ürün, çalışma ortamındaki ilişkiler, örgütsel yapı, teknolojik yapılar ile yönetim ve denetim biçimleri olduğunu söylemektedir. Genel anlamda ise yabancılaşmanın işgörenin içinde bulunduğu bireysel, toplumsal ve kültürel etkenlerden kaynaklanabileceğini söylemektedir. Aiken ve Hage (1966) ve Sarros, Tanewski, Winter, Santora ve Densten (2002) ise bireysel özerkliğin ve karara katılmanın kısıtlı olduğu aşırı bürokratik ve merkezi yapıdaki örgütlerin buna neden olduğunu belirtmektedir. Değer ve kabul görmeyen çalışanlar katı yönetim etkisinde, kendilerinin sadece üretim yapan robotlar olarak görüldüğü hissine kapılır. Bu durumda yabancılaşma bir tepki biçimi olarak ortaya çıkar. Yalnızlık hissi ve işe bağlılığın azalmasıyla birlikte çalışanın işe ve örgüte karşı yabancılaşmasına neden olabilir (Şimşek, Çelik, Akgemci ve Fettahlıŏlu, 2006, s. 575). Okullarda ise yönetimin öğretmenlerin beklentilerini yerine getirmemeleri durumunda yabancılaşma yaşanabilmektedir (LeCompte ve Dworkin, 1991). Öğretmenlerde örgütsel yabancılaşma onların genel sağlık durumu, iş performansı, işe devam, mesleki doyum, verimli çalışma, okul bağlılığı üzerinde olumsuz etkilere neden olduğundan eğitimin niteliği için üzerinde durulması gereken bir konudur.

Okullarda farklı özelliklere sahip öğretmenlerin birlikte uyum içinde çalışabilmesi ve bu farklılıkların değer görmesi iş yaşam kalitesini artırıp olumlu sonuçlar ortaya çıarırken (Akar, 2018; Erdem, 2014), farklılıkların etkili şekilde yönetilmiyor olması okul ve öğretmenler açısından olumsuz sonuçlar ortaya çıkarabilmektedir. Bu olumsuz sonuçlardan biri de yabancılaşma düzeylerinin artmasıdır (Çavuş, Kapusuz ve Biçer, 2016). İnsan kaynaklarının yönetimi, uygulanacak yönetsel politikalar ile örgütün yabancılaşmayı anlama ve yönetme şekli arasında doğrudan ilişkiler bulunmaktadır. Yabancılaşmanın meydana getirdiği olumsuz şartlar, çalışanları etkilemektedir. Bundan dolayı da örgütsel yaşamda istenilmeyen sonuçlar oluşabilmektedir (Durcan, 2007, s. 12). İş yaşamlarının büyük bölümünü sınıfta geçiren öğretmenler, okulun informal yapısı gereği okul yöneticileri ve diğer öğretmenlerle yoğun etkileşim halindedirler. Özellikle okul yöneticileri ile yaşayacakları olumlu mesleki deneyimler onların daha sağlıklı bir örgüt yaşamı geçirmelerine hizmet edecektir. Keskinkılıç-Kara ve Alabay (2016) okullarda farklılıkların etkili bir şekilde yönetilmesi ile öğretmenlerin arasındaki rekabetin yerini işbirliğinin alabileceğini, birlikte daha iyisi için çalışma ortamının oluşabileceğini ve öğretmenlerin kendilerini ayırılmış veya öteki olarak algılamayıp, bütünün bir parçası olarak algılayabileceklerini vurgulamışlardır. Farklılıkların etkili şekilde yönetilmediği durumlarda ise yabancılaşma gibi olumsuz sonuçlara neden olma potansiyeli bulunmaktadır. Yabancılaşan öğretmen, kurumundan, öğretmenlerden, yöneticililerden uzaklaşan kişidir. Çalıştı̆̆ı okulda sahip olduğu özellikleri ile kabul görmeyen bir öğretmen gerginlik ve huzursuzluk yaşayacak, bu durum da yabancılaşmaya neden olabilecektir. Bu bakımdan farklılıkların yönetiminin öğretmenlerin yabancılaşmasında rol oynayabileceğini belirtmek mümkündür. Bu bağlamda farklılıkların yönetimi ve işlevlerinden, yabancılaşmanın önlenmesi sürecinde yararlanılabilir. Bunun yapılabilmesi için öncelikle yabancılaşmanın ve farklılıkların yönetiminin 
işlevlerinin iyi anlaşılması, farklılıkların yönetiminden yabancılaşmayı önlemede yararlanılması gerekmektedir. Bu sayede, öğretmenlerin yabancılaşmasının düzeyini ve öğretmenlerin mutlu ve sağlıklı çalışabilmelerini sağlamak için alınacak önlemleri bulmak mümkün olabilecektir.

Örgütsel farklılıkların ve beraberindeki yabancılaşmanın önlenmesinde örgütsel hayatın işleyişinde çalışma atmosferinin daha zevkli ve çalışılabilir olması; çalışanların motivasyonunun yüksek olması; işgörenlerin yeni fikirlere açık olması; işgörenler arasında bilgi paylaşımının ve örgütsel iletişimin artması; öğrenme arzusunun süreklilik göstermesi ve örgütsel gelişimin sürekliliğinin hedeflenmesi; örgütün var olan işgörenlerinin işe devamının sağlanmasında etkin rol oynayacaktır (Gökçen ve Çavuş, 2014, s. 531).

Farklılıkların yönetiminin başarıyla uygulanması konusunda, öncelikle yabancılaşma olgusunun kabul edilmesi, örgüt iklimin fiziki ve ruhsal olarak iyileştirilmesi, iş hayatının kalitesinin yükseltilmesi gerekmektedir. Ayrıca işgörenler arasındaki işbirliği, ekip çalışması ve kararlara katılmanın yaygınlaştırılması, strese neden olan durumların önlenmesi önemli olmaktadır. Örgüt üyelerinin moral ve motivasyonlarının arttırılması, örgütlerin farklılıklara olan ihtiyaçlarının belirlenmesi; farklılıkların yönetiminin örgüte kazandıracağı avantajların yöneticilere ve işgörenlere ödüllerle teşvik edilerek artırılması gereklidir (Gökçen ve Çavuş, 2014, s. 531).

Farklılıkların yönetimi ve yabancılaşma kavramlarına ilişkin ilgili alan yazını incelendiğinde, bu iki kavramın birlikte çalışıldığı araştırmalara rastlanmamıştır. Ayrıca bu kavramlar birlikte eğitim örgütleri açısından da ele alınıp irdelenmemiştir. Bu bağlamda bu araştırmada, farklılıkların yönetiminin, eğitim örgütlerinde örgütsel yabancılaşmayı etkileme olasılığından yola çıkılarak, eğitim işgörenlerinin en kalabalık kesimini oluşturan öğretmenlerin farklılıkların yönetimi ile örgütsel yabancılaşması arasındaki ilişkiye dair algılarını ortaya çıkarmak amaçlanmış olup, "Farklılıkların yönetimi örgütsel yabancılaşmayı yordamakta mıdır?" sorusunun yanıtı aranmıştır. Bu problem doğrultusunda, aşağıdaki sorular araştırmanın alt problemlerini oluşturmaktadır:

1.Öğretmenlerin farklılıkların yönetimine ilişkin görüşleri ne düzeydedir?

2.Öğretmenlerin örgütsel yabancılaşma durumları ne düzeydedir?

3.Farklılıkların yönetimi ile örgütsel yabancılaşma arasında anlamlı bir ilişki var mıdır?

4.Farklılıkların yönetimi örgütsel yabancılaşmanın yordayıcısı mıdır?

\section{Yöntem}

Araştırma yordayıcı ilişkisel tarama modelinde tasarlanmıştır. İlişkisel tarama modelleri, iki ya da daha fazla sayıda değişkenin birlikte değişip değişmediğini ve/veya değişimin hangi düzeyde gerçekleştiğini tespit etmeyi belirlemek için tasarlanan araştırma modelleridir (Karasar, 2011, s. 81).Araştırmanın yordayan değişkeni farklılıkların yönetimi yordanan değişkeni ise örgütsel yabancılaşma olarak belirlenmiştir.

\section{Evren ve Örneklem}

Bu araştırmanın evrenini, İstanbul İli Sultangazi ilçesinde kamuya bağlı okullarda çalışan 3521 öğretmen oluşturmaktadır. Araştırmanın örneklemi evrendeki öğretmenlerden "oranlı tabakalı örnekleme" yöntemi ile seçilen 371 öğretmenden oluşmaktadır. Örneklemin belirlenmesinde ilkokul, ortaokul ve lise okullarının sayıları ile okullardaki öğretmen sayıları dikkate alınmıştır. Tabakalı örnekleme yöntemi ile alt evrenlerin örneklemde yansıtılması teminat altına alınmış olur. Örneklemi belirlerken her alt tabaka ayrı bir basit yansız örnekleme gibi örneklenir (Balc1, 2010, s. 96).

Sultangazi ilçesinde 2017-2018 öğretim yılında eğitim öğretime devam eden 88 tane kamu okulu bulunmaktadır. Bu okulların 3'ü anaokulu, 30'u ilkokul, 39'u ortaokul ve 16'sı ise lisedir. Örneklem belirlenirken, okulların öğretmen sayısı ölçüt kabul edilmiştir. Öğretmen sayısı 26'dan az olan okullar küçük okul, öğretmen sayısı 26-50 arasında olan okullar orta büyüklükteki okul ve 51 ve üzerinde öğretmen sayısı olan okullar da büyük okullar olarak tanımlanmıştır (Elma, 2003, s. 10). Sultangazi ilçesindeki okullar tabakalı örnekleme tekniğine göre büyük, küçük ve orta büyüklükteki okul olmak üzere büyüklüklerine göre üç 
tabakaya ayrılmıştır. İlçedeki 88 okulun 19'unun öğretmen sayısı 26'dan az olduğundan küçük ölçekli okul, 45'inin öğretmen sayısı 26-50 arasında olduğundan, orta ölçekli okul ve 24' ünün öğretmen sayısı 50'den fazla olduğundan büyük ölçekli okul olarak kabul edilmiştir. Örneklem tespitinde hem okul türü hem de okul büyüklüğü dikkate alınmıştır. Okul türüne bağlı olarak 9 ilkokul, 17 ortaokul ve 6 liseden, okul büyüklüğüne göre küçük ölçekli okullardan 5'ine, orta ölçekli okullardan 20'sine ve büyük ölçekli okullardan 7' sine ölçekler ulaştırılarak veriler toplanmıştır. Okullara elden toplam 450 ölçek ulaştırılmış, ulaştırılan ölçeklerden 405 tanesi geri dönmüş olup, dönen anketlerden eksik bilgiler çıkarıldığında 371 ölçek değerlendirmeye alınmıştır.

Araştırmaya katılan öğretmenlerin demografik özellikleri Tablo I’de gösterilmiştir.

Tablo I

Araştırmaya Katılan Öğretmenlerin Demografik Dağılım Tablosu

\begin{tabular}{|c|c|c|c|}
\hline Değişkenler & Gruplar & Frekans & Yüzde \\
\hline \multirow{2}{*}{ Cinsiyet } & Kadın & 183 & 49,3 \\
\hline & Erkek & 188 & 50,7 \\
\hline \multirow{4}{*}{ Yaş } & 21 - 30 Yaş & 122 & 32,9 \\
\hline & $31-40$ Yaş & 110 & 29,6 \\
\hline & 41 - 50 Yaş & 80 & 21,6 \\
\hline & 51 ve üzeri & 59 & 15,9 \\
\hline \multirow{2}{*}{ Medeni Durum } & Evli & 249 & 67,1 \\
\hline & Bekar & 122 & 32,9 \\
\hline \multirow{2}{*}{ Öğrenim Durumu } & Lisans & 316 & 85,2 \\
\hline & Lisansüstü & 55 & 14,8 \\
\hline \multirow{5}{*}{ Mesleki Kıdem } & $1-6 Y_{11}$ & 105 & 28,3 \\
\hline & $7-12 Y_{11}$ & 93 & 25,1 \\
\hline & $13-18 Y_{11}$ & 69 & 18,6 \\
\hline & $19-24 Y_{11}$ & 59 & 15,9 \\
\hline & 25 ve Üzeri & 45 & 12,1 \\
\hline \multirow{3}{*}{ Okul Büyüklüğü } & Küçük okul (0-25) & 104 & 28,3 \\
\hline & Ortaokul (26-50) & 143 & 38,3 \\
\hline & Büyük Okul (51 ve üzeri ) & 124 & 33,4 \\
\hline \multirow{3}{*}{ Okul Türü } & İlkokul & 139 & 37,5 \\
\hline & Ortaokul & 128 & 34,5 \\
\hline & Lise & 104 & 28 \\
\hline \multirow{2}{*}{ Branş } & Sınıf Öğretmeni & 131 & 35,3 \\
\hline & Branş Öğretmeni & 240 & 64,7 \\
\hline Toplam & & 371 & 100 \\
\hline
\end{tabular}

\section{Veri Toplama Araçları}

Araştırma verileri Balay ve Sağlam (2004) tarafından geliştirilmiş olan "Farklılıkların Yönetimi Ölçeği" ve Elma (2003) tarafından geliştirilmiş olan "İlköğretim Okulu Öğretmenlerinin İşe Yabancılaşması Ölçeği” aracılığıyla elde edilmiştir. Öğretmenlerin demografik özelliklerini belirlemek amacıyla ayrıca kişisel bilgi formundan da yararlanılmıştır.

"Farklılıkların Yönetimi Ölçeği" (FYÖ) 30 maddeden oluşan beşli likert tipinde bir ölçek olup, (1) Hiç Katılmıyorum, (2) Katılmıyorum, (3) Orta Düzeyde Katılıyorum, (4) Katılıyorum ve (5) Tam Katılıyorum olarak derecelendirilmiştir. Araştırma kapsamında yapılan güvenirlik analizi sonrası ölçeğin Cronbach Alpha değerinin $.97(\alpha=.96)$ olduğu görülmüştür. Ölçeğin alt boyutlarına ait güvenirlik değerleri ise 1 . alt boyut $\alpha=.89$, 2. alt boyut $\alpha=.92$, 3. alt boyut $\alpha=.98$ olarak tespit edilmiştir. Bu değerler, maddeler arasında yüksek derecede güvenirliğinin olduğunu göstermektedir.

Öğretmenlerin işe yabancılaşma düzeylerini ölçmek için kullanılan “illköğretim Okulu Öğretmenlerinin İşe Yabancılaşması Ölçeği" beşli likert tipindedir ve güçsüzlük, anlamsızlık, yalıtılmışlık ve okula yabancılaşma boyutlarından oluşmaktadır. Ölçek, (5) her zaman, (4) çoğu zaman, (3) bazen, (2) nadiren ve (1) hiçbir zaman seçeneklerinden oluşmuştur. Araştırma kapsamında yapılan güvenirlik analizi sonrası ölçeğin Cronbach Alpha değerinin $.89(\alpha=.89)$ olduğu, görülmüştür. Ölçeğin alt boyutlarına ait güvenirlik değerleri ise 1. alt boyut $\alpha=.95,2$. alt boyut $\alpha=.93$, 3. alt boyut $\alpha=.91$, 4. alt boyut $\alpha=.98$ olarak tespit edilmiştir. Bu 
değerler, maddeler arasında yüksek derecede güvenirliğinin olduğunu göstermektedir.

\section{Verilerin Çözümlenmesi}

Araştırmada toplanan veriler, sosyal bilimler için geliştirilmiş olan bir istatistik programı kullanılarak çözümlenmiştir. Öğretmenlerin kişisel özelliklerine ait bulgular için frekans ve yüzde kullanılmıştır. Öğretmenlerin farklılıkların yönetimine ve örgütsel yabancılaşmaya ilişkin alg1 düzeylerini saptamak amacıyla, yüzde, frekans, aritmetik ortalama ve standart sapma kullanılmıştır. Ayrıca farklılıkların yönetimi ile örgütsel yabancılaşma arasındaki ilişkiyi anlayabilmek için korelasyon testi uygulanmıştır. Farklılıkların yönetiminin örgütsel yabancılaşmayı yordayıp yordamadığını ortaya çıkarabilmek için regresyon analiz tekniği kullanılarak analize tabi tutulmuştur. Araştırmada, anlamlılık düzeyi $p<0,05$ olarak kabul edilmiştir.

\section{Bulgular}

\section{Öğretmenlerin Farklılıkların Yönetimine İlişkin Görüşlerine Yönelik Bulgular}

Farklılıkların yönetimine ilişkin öğretmen görüşleri alt boyutlar halinde ortalamalar ve standard sapma şeklinde tablolaştırılarak gösterilmiştir.

Tablo II

Öğretmenlerin Bireysel Tutum ve Davranışlar Alt Boyutuna Ilişkin Görüşlerinin Ortalamalar Tablosu

\begin{tabular}{lcc}
\hline İfadeler & X & ss \\
\hline F2. Öğretmenler, meslektaşlarının bilgi ve becerilerini geliştirme çabalarını desteklerler. & 3,35 & 1,061 \\
\hline F4. Öğretmenler, bireysel sorunlarını çözerken meslektaşlarının farklı deneyimlerine ihtiyaç duyarlar. & 3,10 & 1,035 \\
\hline F5.Öğretmenler, meslektaşları arasındaki farklı düşünme eğilimlerini hoş karşılarlar. & 3,25 & 1,166 \\
\hline F6.Öğretmenler, meslektaşları arasındaki davranış farklılıklarını doğal kabul ederler. & 3,28 & 1,043 \\
\hline Bireysel Tutum ve Davranışlar & 3.24 & .93 \\
\hline
\end{tabular}

Tablo II'de görüldüğü üzere boyutun toplam değerleri incelendiğinde; öğretmenlerin ( $X=3.24$ / 12.97) okullarda yüksek oranda pozitif yönde bireysel tutum ve davranışlar ortaya konulduğu yönünde fikir beyan ettikleri görülmektedir. Farklılıkların yönetimi ölçeğinin, bireysel tutum ve davranışlar boyutunda öğretmenlerin en fazla katıldığı madde "Öğretmenler, meslektaşlarının bilgi ve becerilerini geliştirme çabalarını desteklerler." ( $X=3,35)$ iken en az katıldıkları madde ise "Öğretmenler, bireysel sorunlarını çözerken meslektaşlarının farklı deneyimlerine ihtiyaç duyarlar." $(X=3,1)$ maddesi olduğu görülmüştür. Bu bulgulara göre katılımcıların, bireysel tutum ve davranışlar boyutundaki ifadelere orta derecede katıldıkları görülmektedir.

Tablo III

Öğretmenlerin Örgütsel Değerler ve Normlar Alt Boyutuna İlişkin Görüşlerinin Ortalamalar Tablosu

\begin{tabular}{lcc}
\hline İfadeler & X & ss \\
\hline F7. Öğretmenler, meslektaşları arasındaki farklı yaşam biçimlerine saygı duyarlar. & 3,16 & 0,97 \\
\hline F8. Öğretmenler, meslektaşlarını anlamada empatik davranışlar geliştirirler. & 3,18 & 0,98 \\
\hline $\begin{array}{l}\text { F9. Öğretmenler, bir konu hakkında ikna olduklarında kendi davranışlarını olumlu yönde değiştirme } \\
\text { eğilimi gösterirler. }\end{array}$ & 2,93 & 1,04 \\
\hline F10.Öğretmenler ilişkilerinde, önyargılardan çok, esnek düşünme eğilimindedirler. & 3,09 & 0,99 \\
\hline F11.Öğretmenler, kişisel anlayışlarını ileriye götürecek görüş alışverişlerine daima açıktırlar. & 3,33 & 0,94 \\
\hline F12.Öğretmenler, kendilerinden farklı kişilik stiline sahip olanlarla iletişim kurabilirler. & 3,21 & 1,00 \\
\hline Örgütsel Değerler ve Normlar & 3,13 & 1.10 \\
\hline
\end{tabular}

Tablo III'e göre; örgütsel değerler ve normlar boyutunda katılımcıların en çok katıldıkları maddeler, “Öğretmenler, kişisel anlayışlarını ileriye götürecek görüş alışverişlerine daima açıktırlar." $(X=3,33)$ ve "Öğretmenler, kendilerinden farklı kişilik stiline sahip olanlarla iletişim kurabilirler." $(X=3,21)$ maddeleridir. En az katıldıkları ifadeler ise "Öğretmenler ilişkilerinde, önyargılardan çok, esnek düşünme eğilimindedirler." $(X=3,09)$ ve "Öğretmenler, bir konu hakkında ikna olduklarında kendi davranışlarını olumlu yönde değiştirme eğilimi gösterirler." $(X=2,93)$ ifadeleri olduğu görülmüştür. Araştırma sonucuna göre öğretmenlerin farklıklara saygı gösterdikleri ancak önyargılarından kurtulamadıkları ortaya çıkmıştır. Ayrıca öğretmenlerin kendi davranışlarını olumlu yönde değiştirme eğiliminin yüksek olmadığı sonucuna ulaşılmıştır. Farklılıklara saygı esasına dayalı pozitif anlayış ve yaklaşımların ortaya konması yönünde örgütsel değer ve normların 
Örgütsel Yabancılaşmanın Yordayıcısı Olarak Farklılıkların...

oluştuğu ifade edilebilir. Öğretmenlerin örgütsel değerler ve normlar boyutundaki ifadelere orta derecede katıldıkları görülmektedir.

Tablo IV

Öğretmenlerin Yönetsel Uygulamalar ve Politikalar Alt Boyutuna İlişkin Görüşlerinin Ortalamalar Tablosu

\begin{tabular}{|c|c|c|}
\hline İfadeler & $\mathbf{X}$ & ss \\
\hline $\begin{array}{l}\text { F14.Yöneticiler, eğitim ve yönetim etkinliklerini, çalışanların farklı beklentilerini karşlayacak biçimde } \\
\text { yürütmeye çalışırlar. }\end{array}$ & 2,85 & 1,00 \\
\hline F15.Yöneticiler, çalışanların, okulun hizmet ve olanaklarından eşit oranda yararlanmalarını sağlarlar. & 3,06 & 1,1 \\
\hline F16.Yöneticiler, çalışanlara bilgi ve becerilerini sergileyebilecekleri bir ortam yaratmaya çalışırlar. & 3,03 & 1,04 \\
\hline F17.Yöneticiler, çalışanlar arasında statü farklılıkları nedeniyle ayrımcılık yapmazlar. & 3,01 & 1,23 \\
\hline F18.Yöneticiler, farklı kültürel değerler arasında yaşanan çatışmaları çözme kararlılı̆̆ı içindedirler. & 3,00 & 1,12 \\
\hline F19.Yöneticiler, çalışanlar arasında cinsiyet ayırımı yapılmamasına özen gösterirler. & 3,18 & 1,29 \\
\hline $\begin{array}{l}\text { F20.Yöneticiler, önceden belirlenen ödül ve ceza sisteminin ekonomik düzeylerine bakılmaksızın bütün } \\
\text { çalışanlara eşit biçimde uygulanması konusunda duyarlılık gösterirler. }\end{array}$ & 2,97 & 1,18 \\
\hline $\begin{array}{l}\text { F22.Yöneticiler, çalışanları değerlendirirken onların, siyasi görüşlerinden çok, gösterdikleri yararlılık ve başarı } \\
\text { durumuna bakarlar. }\end{array}$ & 2,98 & 1,30 \\
\hline $\begin{array}{l}\text { F23.Yöneticiler, okulu ilgilendiren çeşitli sorunlara ilişkin önemli kararlarda çalışanların farklı çözüm } \\
\text { önerilerini dikkate alırlar. }\end{array}$ & 2,96 & 1,11 \\
\hline F24.Yöneticiler, eğitim-öğretime ilişkin görevlendirmelerde bütün çalışanlara adil davranırlar. & 2,88 & 1,20 \\
\hline F25.Yöneticiler, herhangi bir konuda çalışanların farklı yaklaşım sergilemelerine olumlu yaklaşırlar. & 2,98 & 1,07 \\
\hline F26.Yöneticiler, kişisel farkl1lıklardan kaynaklanan çatışmaları çözmede etkin çaba gösterirler. & 2,98 & 1,01 \\
\hline F27.Yöneticiler, çalışanların, eğitim-öğretime ilişkin işlerde değişiklik yaratma isteklerine olumlu bakarlar. & 3,15 & 0,98 \\
\hline $\begin{array}{l}\text { F28.Yöneticiler, farklı kişisel özelliklere sahip çalışanlara yönelik tutum ve davranışlarında sorumluluk } \\
\text { duygusuyla hareket ederler. }\end{array}$ & 3,01 & 1,03 \\
\hline F29.Yöneticiler, okulun amaçlarını gerçekleştirmede farklı becerilere sahip öğretmenlerden yararlanırlar. & 3,26 & 1,03 \\
\hline F30.Öğretmenler, meslektaşlarının farklı bilgi ve becerilerinin önemli olduğuna inanırlar. & 3,34 & 1,05 \\
\hline Yönetsel Uygulamalar ve Politikalar & 4,42 & ,56 \\
\hline
\end{tabular}

Tablo IV'deki yönetsel uygulamaların ve politikalar boyutunun toplam değerleri incelendiğinde; öğretmenlerin okullarda farklılıklara yönelik yönetsel uygulamaları ve politikaları olumlu olarak değerlendirdiği, yönetimsel politikalar ve işlemlerde farklılıkların göz önünde bulundurulduğu ve farklılıklara saygılı bir yönetsel yaklaşımın sergilendiği görüşüne "çok" ( $X=4,42 / 48,64)$ düzeyinde katıldığı görülmektedir. Bu sonuç, araştırma yapılan okullarda farklılıkların okulu zenginleştiren bir özellik olarak görüldüğü, farklılıklara saygılı olunduğu ve eğitim kurumları yönetilirken farklılıkların önemsendiğini göstermektedir. Farklılıkların yönetiminin yönetsel uygulamalar ve politikalar boyutunda öğretmenlerin en fazla katılmış oldukları maddeler "Öğretmenler, meslektaşlarının farklı bilgi ve becerilerinin önemli olduğuna inanırlar." ( $X=3,34)$ ve "Yöneticiler, okulun amaçlarını gerçekleştirmede farklı becerilere sahip öğretmenlerden yararlanırlar." $(X=3,26)$ maddeleridir. "Yöneticiler, eğitim-öğretime ilişkin görevlendirmelerde bütün çalışanlara adil davranırlar." $(X=2,88)$ ve "Yöneticiler, eğitim ve yönetim etkinliklerini, çalışanların farklı beklentilerini karşılayacak biçimde yürütmeye çalışırlar." ( $X=2,85)$ maddelerinin ise öğretmenlerin en az katıldıkları maddeler olduğu görülmektedir.

Araştırma kapsamında elde edilen veriler incelendiğinde; öğretmenlerin farklılıklar yönetimi ölçeğinde en yüksek puanı yönetsel uygulamalar ve politikalar alt boyutunda elde ettiği $(X=4,42)$, en düşük puanı ise örgütsel değerler ve normlar $(X=3,13)$ alt boyutunda elde ettiği tespit edilmiştir.

\section{Öğretmenlerin Örgütsel Yabancılaşma Düzeyine İlişkin Bulgular}

Araştırmaya katılan öğretmenlerin örgütsel yabancılaşma düzeyleri güçsüzlük, anlamsızlık, yalıtılmışlık ve okula yabancılaşma boyutlarında incelenmiş olup aritmetik ortalamaları ve standard sapmaları aşağıda tablolaştırılmıştır. Örgütsel yabancılaşma düzeylerine ilişkin bulgular sunulmuştur.

Tablo V

Öğretmenlerin Güçsüzlük Boyutuna Ait Örgütsel Yabancllaşma Düzeylerine İlişkin Bulgular Tablosu

\begin{tabular}{lll}
\hline Güçsüzlük Boyutunun Maddeleri & X & ss \\
\hline Y1. Okuldaki sorunlarla mücadele etme gücümü yitirdiğimi hissediyorum. & 2,54 & 1,07 \\
\hline Y2.Öğrencilerimle iletişim kurmakta zorlanıyorum. & 2,13 & 1,02 \\
\hline Y3. İşimde tükendiğimi, yıprandığımı hissediyorum. & 2,33 & 1,05 \\
\hline
\end{tabular}




\begin{tabular}{lll}
\hline Y5.Çalışma istek ve heyecanımı yitirdiğimi hissediyorum. & 2,30 & 1,11 \\
\hline Y6.İş yaşamımda her şeyin benim dışımda geliştiğini hissediyorum. & 2,58 & 1,15 \\
\hline Y7.Son zamanlarda öğretmenlikten soğuduğumu hissediyorum. & 2,30 & 1,15 \\
\hline Y8.Okulda gereksinim duyduğum sosyal desteği alamadığımı hissediyorum. & 2,64 & 1,23 \\
\hline Y9.Okulda doğruları savunmanın artık yarar getirmediğini düşünüyorum. & 2,87 & 1,27 \\
\hline Y10.Okuldaki kuralların yaratıcılığımı engellediğini düşünüyorum. & 2,70 & 1,21 \\
\hline Güçsüzlük & 2,75 &, 90 \\
\hline
\end{tabular}

Tablo V incelendiğinde; araştırmaya katılan öğretmenlerin güçsüzlük boyutunda örgütsel yabancılaşma düzeyine ilişkin algılarına göre öğretmenlerin en fazla katıldıkları ifadeler, "Okulda doğruları savunmanın artık yarar getirmediğini düşünüyorum." $(X=2,87)$ ve "Okuldaki kuralların yaratıcılı̆̆ımı engellediğini düşünüyorum." ( $X=2,70)$ maddeleri iken öğretmenlerin en az katıldıkları maddeler ise "Öğrencilerimle iletişim kurmakta zorlanıyorum." $(X=2,13)$, "Çalışma istek ve heyecanımı yitirdiğimi hissediyorum." $(X=2,30)$ ve "Son zamanlarda öğretmenlikten soğuduğumu hissediyorum." ( $X=2,30)$ maddeleridir. Öğretmenlerin okulda doğruları savunmak ve kuralları yaratıcıllğa hizmet edecek biçimde dönüştürmek konusunda kendilerini daha güçsüz hissettikleri görülmektedir. Öğretmenlerin, "Okulda doğruları savunmanın artık yarar getirmediğini düşünüyorum." biçimindeki ifadeye en fazla katılmaları genel anlamda Türkiye'de yolsuzluklara bulaşanların gerekli cezayı görmemeleri, okullarda mesleğin etik kurallarına aykırı davrananların bir anlamda ödüllendirildiğine ilişkin algılarına bağlanabilir. Bunun yanı sıra sistemi düzeltmeye yönelik çabaların sonuçsuz kalmasının ya da sistemdeki yanlışlıkları düzeltmeye güçlerinin yetmemesinin de bir etkisi olabilir (Elma, 2003). Öğretmenlerin işlerine ilişkin; işten soğumalarının düşük olması, çalışma istek ve heyecanlarını yitirmemiş olmaları ve öğrencileriyle ilişkilerinde ve iletişiminde zorlanmadıkları görülmektedir. Öğretmenlerin örgütsel yabancılaşmaya ilişkin algılarının güçsüzlük boyutunda bazen düzeyinde olduğu görülmektedir $(X=2,75)$.

\section{Tablo VI}

Öğretmenlerin Anlamsızlık Boyutuna Ait Örgütsel Yabancılaşma Düzeylerine İlişkin Bulgular Tablosu

\begin{tabular}{lll}
\hline Anlamsızlık Alt Boyutunun Maddeleri & X & ss \\
\hline Y12.Okulda öğretilenlerin gerçek yaşamda hiçbir işe yaramadığını düşünüyorum. & 2,22 & 1,22 \\
\hline Y13.Okulda aynı konuları öğretmekten bıktığımı hissediyorum. & 2,26 & 1,13 \\
\hline Y14.Okulda kendimi anlamsız bir iş yapıyormuşum gibi hissediyorum. & 1,94 & 1,13 \\
\hline Y15.İdealist öğretmenleri gördükçe, öğretmenlikten uzaklaştığım duygusunu yaşıyorum. & 1,82 & 1,07 \\
\hline Y16.Bir öğretmen olarak kendimi işe yaramaz ve önemsiz hissediyorum. & 1,79 & 1,08 \\
\hline Y17.Öğretme eyleminin anlamsız bir çaba olduğunu düşünüyorum. & 1,71 & 1,01 \\
\hline Y18.Öğretmenliği sıkıcı buluyorum. & 1,92 \\
\hline Y19.Öğretmenliği sadece gelir getirici bir kaynak olarak görüyorum. & 1,67 & 1,06 \\
\hline Y20.Okulda, ders verme makinesine dönüştüğümü hissediyorum. & 2,13 & 1,08 \\
\hline Y21.Öğretmenliğin benim için monotonlaşmaya başladı̆̆ını hissediyorum. & 2,33 & 1,15 \\
\hline Anlamsizlı & 2.00 & 1,06 \\
\hline
\end{tabular}

Tablo VI incelendiğinde; araştırmaya katılan öğretmenlerin anlamsızlık boyutunda örgütsel yabancılaşma düzeyine ilişkin algılarına göre öğretmenlerin en çok katıldıkları maddeler, "Okulda aynı konuları öğretmekten bıktığımı hissediyorum." ( $X=2,26)$ ve "Öğretmenliğin benim için monotonlaşmaya başladığını hissediyorum." ( $X=2,33)$ maddeleri iken "Öğretme eyleminin anlamsız bir çaba olduğunu düşünüyorum." $(X=1,71)$ ve "Öğretmenliği sadece gelir getirici bir kaynak olarak görüyorum." $(X=1,67)$ maddeleri ise en az katıldıkları maddelerdir. Öğretmenler, anlamsızlık boyutunda her yıl aynı konuları öğretmenin usanç verici bir hal aldığını, öğretmen mesleğinin kendisi açısından tekdüzeleştiğini, okulda öğretilen bilgilerin öğrencilere gelecek yaşamlarında faydalı olmadığı şeklinde düşündüklerini belirtmişlerdir. Ayrıca öğretmenler, anlamsızlık boyutunda yaptıkları işin anlamsız bir çaba olmadığını ve öğretmenliği sadece gelir getirici bir kaynak olarak görmediklerini ifade etmişlerdir. Öğretmenlerin örgütsel yabancılaşmaya ilişkin algılarının anlamsızlık boyutunda nadiren $(X=2,00)$ düzeyinde olduğu görülmektedir.

Tablo VII

Öğretmenlerin Yalıtılmışlık Boyutuna Ait Örgütsel Yabancılaşma Düzeylerine İlişkin Bulgular Tablosu

\begin{tabular}{lcc}
\hline Yalıtılmışlık Alt Boyutunun Maddeleri & X & ss \\
\hline Y22.Zorunlu olmadıkça diğer öğretmen ve yöneticilerle bir araya gelmemeye çalışıyorum. & 1,92 & 1,18 \\
\hline Y23.Okulda dışlandığım duygusunu yaşıyorum. & 1,65 & 1,00 \\
\hline
\end{tabular}


Örgütsel Yabancılaşmanın Yordayıcısı Olarak Farklılıkların...

\begin{tabular}{lll}
\hline Y24.Öğretmenler odasından uzak durmayı tercih ediyorum. & 1,76 & 1,12 \\
\hline Y25.Okuldaki ilişkilerin içten ve samimi olmadı̆̆ını düşünüyorum. & 2,42 & 1,21 \\
\hline Y26.Okulda kendimi yalnız hissediyorum. & 1,90 & 1,11 \\
\hline Y27.Sınıf dışı etkinliklerde sorumluluk üstlenmeyi sevmiyorum. & 2,26 & 1,20 \\
\hline Y28.Okuldaki diğer öğretmenlerle, okul dışında bir şeyler yapmayı arzulamıorum. & 1,92 & 1,24 \\
\hline Y29.Sosyal çevremi çok sıkıcı buluyorum. & 1,92 & 1,06 \\
\hline Y30.Yaşamımda bir boşluk duygusu yaşıyorum. & 2,01 & 1,07 \\
\hline Y31.Aynı görüşte olmadığım insanlardan uzak durmayı yeğliyorum. & 2,11 & 1,14 \\
\hline Yalıtılmışlı & 1.98 &, 90 \\
\hline
\end{tabular}

Tablo VII incelendiğinde; araştırmaya katılan öğretmenlerin yalıtılmışlık boyutunda örgütsel yabancılaşma düzeyine ilişkin algılarına göre öğretmenlerin en az katıldıkları maddeler, "Okulda dışlandığım duygusunu yaşıyorum." ( $X=1,65)$ ve "Öğretmenler odasından uzak durmayı tercih ediyorum." $(X=1,76)$ maddeleri iken "Sınıf dışı etkinliklerde sorumluluk üstlenmeyi sevmiyorum." $(X=2,26)$ ve "Okuldaki ilişkilerin içten ve samimi olmadığını düşünüyorum." $(X=2,42)$ maddeleri ise en çok katıldıkları maddelerdir. Öğretmenler nadiren de olsa okuldaki ilişkilerin samimi ve içten olmadığını, sınıf dışı etkinliklerde görev almayı sevmediklerini, kendileriyle aynı görüşten olmayan kişilerle bir arada olmayı istemediklerini belirtmişlerdir. Öğretmenler okulda dışlanmışlık ve yalnızlık yaşamadıklarını, öğretmenler odası gibi kaynaşmanın gerçekleştiği mekânlardan uzak durmayı tercih etmediklerini ifade etmişlerdir. Öğretmenlerin örgütsel yabancılaşmaya ilişkin algılarının yalıtılmışlık boyutunda nadiren düzeyinde olduğu görülmektedir $(X=1,987)$. Elma, 2003 yılında yapmış olduğu çalışmasında, öğretmenlerin yalıtılmışlık boyutuna ilişkin işe yabancılaşma düzeylerini "Nadiren" olarak tespit edilmiştir. Bu bulgu, araştırma bulgusuyla paralellik içermektedir. Ayrıca öğretmenlerin görüşlerine göre örgütsel yabancılaşmanın en düşük düzeyde yaşandığı boyut yalıtılmışlık boyutunda ortaya çıkmaktadır.

Tablo VIII

Öğretmenlerin Okula Yabancılaşma Boyutuna Ait Örgütsel Yabancılaşma Düzeylerine İlişkin Bulgular Tablosu

\begin{tabular}{lcc}
\hline Okula Yabancılaşma Alt Boyutunun Maddeleri & X & ss \\
\hline Y32.Okulda olmadı̆̆ım zamanlarda kendimi boşluktaymış gibi hissediyorum. & 2,43 & 1,30 \\
\hline Y33.Meslektaşlarım tarafından takdir edilmeyi önemsiyorum. & 2,93 & 1,42 \\
\hline Y34.Öğretmenliğin yapılabilecek en iyi meslek olduğunu düşünüyorum. & 3,31 & 1,39 \\
\hline Y35.Okulda işim ile ilgili konularda sorumluluk almaktan zevk alıyorum. & 3,40 & 1,37 \\
\hline Y36.Okulda kurallara aykırı davrandığımda suçluluk duygusu yaşıorum. & 2,97 & 1,34 \\
\hline Y37.Öğrencilerimin başarı ya da başarısızlı̆̆ından kendimi sorumlu tutuyorum. & 2,94 & 1,27 \\
\hline Y38.Okulda sınıftayken kendimi daha rahat hissediyorum. & 3,63 & 1,37 \\
\hline Okula Yabancılaşma & 3.08 & 1,08 \\
\hline
\end{tabular}

Tablo VIII incelendiğinde; araştırmaya katılan öğretmenlerin okula yabancılaşma boyutunda örgütsel yabancılaşma düzeyine ilişkin algılarına göre öğretmenlerin en çok katıldıkları maddeler, "Okulda işim ile ilgili konularda sorumluluk almaktan zevk alıyorum." $(X=3,40)$ ve "Okulda sinıftayken kendimi daha rahat hissediyorum." (X=3,63) maddeleridir. Öğretmenlerin, okulda çoğu zaman kendilerini en rahat hissettikleri yerin sinıflar olduğu, okulda işiyle ilgili konularda sorumluluk almaktan zevk aldıkları ve öğretmenliğin yapılabilecek en iyi meslek olduğunu düşündükleri görülmektedir. Öğretmenlerin okul ortamında kendilerini en rahat ve huzurlu hissettikleri yerin sınıflar olmasının nedenleri; sınıfların eğitim-öğretim sürecinin ana birimleri olması, öğretmenlerin kendilerini en iyi ifade ettikleri, sağlıklı ve etkili iletişimi kurabildikleri yerler olmasına bağlanabilir (Elma, 2003). Özellikle güçsüzlük boyutunda "Öğrencilerimle iletişim kurmakta zorlanıyorum." ifadesine nadiren düzeyinde katılım göstermeleri, öğretmenlerin en iyi iletişim kurabildikleri ortamın sınıflar olduğunu göstermektedir. Araştırmaya katılan öğretmenlerin Okulda olmadığım zamanlarda kendimi boşluktaymış gibi hissediyorum." $(X=2,43)$ ve "Meslektaşlarım tarafından takdir edilmeyi önemsiyorum." $(X=2,93)$ maddeleri ise en az katıldıkları maddelerdir. Öğretmenlerin okulda olmadığı zamanlarda kendilerini boşlukta hissetme algilarının düşük oluşu, iş ve iş dışı yaşam arasında bir denge kurdukları şeklinde yorumlanabilir (Elma, 2003). Ayrıca öğretmenlerin, meslektaşları tarafından takdir edilmeyi önemsemedikleri görülmektedir. Öğretmenlerin örgütsel yabancılaşmaya ilişkin algılarının okula yabancılaşma boyutunda bazen düzeyinde olduğu görülmektedir $(X=3,087)$. Öğretmenlerin örgütsel yabancılaşmayı en yüksek düzeyde algıladıkları boyutun okula yabancılaşma olduğu ortaya çıkmaktadır. 
Öğretmenlerin örgütsel yabancılaşmayı en fazla okula yabancılaşma boyutunda yaşamalarına yönelik bu bulgu Celep (2008), Çalışır (2006), Elma (2003), Erjem (2005), Şirin (2009), Yılmaz ve Sarpkaya (2009)'nın araştırma bulgularıyla benzerlik göstermektedir.

\section{Öğretmenlerin Farklılıkların Yönetimine İlişkin Görüşleri ile Örgütsel Yabancılaşma Düzeylerine İlişkin Algıları Arasındaki İlişkinin Bulguları}

Öğretmenlerin farklılıkların yönetimine ilişkin görüşleri ile örgütsel yabancılaşma düzeylerine yönelik algıları arasında anlamlı bir ilişkinin olup olmadığını belirlemek amacıyla korelasyon testi uygulanmıştır. Korelasyon test sonuçları Tablo IX' de gösterilmiştir.

Tablo IX

Öğretmenlerin Farklılıklarnn Yönetimine İlişkin Görüşleri ile Örgütsel Yabancılaşma Düzeylerine İlişkin Algıları Arasındaki Korelasyon Analizinin Tablosu

\begin{tabular}{|c|c|c|c|c|c|c|}
\hline & 1 & 2 & 3 & 4 & 5 & 6 \\
\hline \multicolumn{7}{|l|}{ Okula Yabancılaşma } \\
\hline Yalıtılmışlık & $748^{* *}$ & & & & & \\
\hline Anlamsızlık & $658^{* *}$ & $790^{* *}$ & & & & \\
\hline Güçsüzlük &, $596^{* *}$ & ,754 &, $727^{* *}$ & & & \\
\hline Bireysel Tutum ve Davranışlar &,$- 492^{* *}$ &,$- 649^{* *}$ &,$- 532^{* *}$ &,$- 596^{* *}$ & & \\
\hline Örgütsel Değerler ve Normlar &,$- 475^{* *}$ &,$- 633^{* *}$ &,$- 474^{* *}$ &,$- 627^{* *}$ & ,791* & \\
\hline Yönetsel Uygulamalar ve Politikalar &,$- 517^{* *}$ &,$- 591^{* *}$ &,$- 514^{* *}$ &,$- 659^{* *}$ & $619^{* *}$ &, $781^{* *}$ \\
\hline
\end{tabular}

Tablo IX incelendiğinde; araştırmaya katılan öğretmenlerin, elde ettikleri puanlar bağlamında farklılıkların yönetiminin bireysel tutum ve davranışlar boyutu ile örgütsel yabancılaşmanın yalıtılmışlık boyutu arasında olumsuz yönde yüksek düzeyde, güçsüzlük, anlamsızlık ve okula yabancılaşma boyutlarında ise negatif yönlü orta düzeyde bir ilişki saptanmıştır. Bu sonuçlara göre öğretmenlerin farklılıkların yönetiminin bireysel tutum ve davranışlar boyutundaki algılarında meydana gelecek artmanın öğretmenlerin güçsüzlük, anlamsızlık ve okula yabancılaşma şeklindeki örgütsel yabancılaşmasını orta düzeyde, yalıtılmışlık biçimindeki örgütsel yabancılaşmasını yüksek düzeyde azaltacağı söylenebilir. Örgütsel değerler ve normlar ile anlamsızlık ve okula yabancılaşma arasında olumsuz yönlü orta seviyede, yalıtılmışlık ve güçsüzlük ile olumsuz yönde yüksek düzeyde bir ilişki olduğu görülmüştür. Bu bulguya göre öğretmenlerin farklılıkların yönetiminin örgütsel değerler ve normlar boyutundaki algılarında meydana gelecek artmanın öğretmenlerin anlamsızlık ve okula yabancılaşma şeklindeki örgütsel yabancılaşmasını orta düzeyde, güçsüzlük ve yalıtılmışlık biçimindeki örgütsel yabancılaşmasını ise yüksek düzeyde azaltacağı söylenebilir. Yönetsel uygulamalar ve politikalar boyutu ile anlamsızlık, yalıtılmışlık ve okula yabancılaşma boyutlarında olumsuz yönde orta düzeyde, güçsüzlük boyutu ile olumsuz yönlü yüksek seviyede bir ilişki olduğu tespit edilmiştir. Bu durum göz önünde bulundurulduğunda, öğretmenlerin farklılıkların yönetiminin yönetsel uygulamalar ve politikalar boyutundaki algılarında meydana gelecek artmanın öğretmenlerin anlamsızlık, yalıtılmışlık ve okula yabancılaşma şeklindeki örgütsel yabancılaşmasını orta düzeyde, güçsüzlük biçimindeki örgütsel yabancılaşmasını ise yüksek düzeyde azaltacağ1 söylenebilir $\left(\mathrm{r}_{(20)}=0,992\right.$; $\mathrm{p}<0,01)$.

\section{Öğretmenlerin, Farklılıkların Yönetimine İlişkin Görüşlerinin Düzeyinin, Örgütsel Yabancılaşmaya İlişkin Algı Düzeyine Etkisinin Bulguları}

Öğretmenlerin, farklılıkların yönetimine ilişkin algı düzeyinin, öğretmenlerin örgütsel yabancılaşma düzeyinin ne kadarını açıkladığını tespit edebilmek için çoklu regresyon analizi uygulanmıştır. Uygulanan regresyon analizine ilişkin bulgular aşağıda gösterilmiştir. Aşağıdaki tablolarda güçsüzlük, anlamsızlık, yalıtılmışlık ve okula yabancılaşma düzeyinin, bireysel tutum ve davranışlar, örgütsel değerler ve normlar ile yönetsel uygulamalar ve politikaları düzeylerinden etkilenme durumunu test etmek için yapılan çoklu doğrusal regresyon modelleri sunulmuştur.

Tablo X

Farklılkların Yönetiminin Boyutlarının Örgütsel Yabancılaşmanın Güçsüzlük Düzeyini Yordamasına İlişkin Regresyon Tablosu

\begin{tabular}{lccccccc}
\hline Bağımlı Değişken & Bağımsız Değişken & $\boldsymbol{\beta}$ & $\boldsymbol{t}$ & $\mathbf{p}$ & $\mathbf{F}$ & $\mathbf{M o d e l}(\mathbf{p})$ & $\mathbf{R}^{2}$ \\
\hline Güçsüzlük & Sabit & 48,157 & 35,889 &, 00 & 118,758 &, 00 &, 493 \\
\hline
\end{tabular}




\begin{tabular}{cccc} 
Bireysel Tutum ve Davranışlar &,- 640 & $-4,373$ &, 00 \\
\hline Örgütsel Değerler ve Normlar &,- 106 & $-1,025$ &, 306 \\
\hline Yönetsel Uygulamalar ve Politikalar &,- 256 & $-7,269$ &, 00
\end{tabular}

Tablo $X$ incelendiğinde; bireysel tutum ve davranışlar, örgütsel değerler ve normlar ile yönetsel uygulamalar ve politikalarının güçsüzlük düzeyini yordamasını sınamak amacıyla uygulanan regresyon modeli istatistiksel olarak anlamlıdır $(\mathrm{F}=118.758 ; \mathrm{p}=0.000)$. Bulgular bağlamda, öğretmenlerin yönetsel uygulamalar ve politikalar boyutundaki puanları bir birim arttığında öğretmenlerin güçsüzlük şeklindeki örgütsel yabancılaşması. 26 birim azalmakta $(\Omega=-0.256 ; t=-7,269 ; \mathrm{p}=0.000<0.05)$, öğretmenlerin bireysel tutum ve davranışlar boyutundaki puanları bir birim arttığında öğretmenlerin güçsüzlük şeklindeki örgütsel yabancılaşması.64 birim azalmaktadır $(B=-0.640 ; t=-4,373 ; p=0.000<0.05)$. Öte yandan örgütsel değerler ve normlar boyutunda meydana gelen değişiklikler güçsüzlük düzeyini istatistiksel olarak etkilememektedir $(t=-1,025 ; \mathrm{p}=0.306>0.05)$. Bireysel tutum ve davranışlar ile yönetsel uygulamalar ve politikalar değişkenleri birlikte, güçsüzlük düzeyini.49 oranında etkilemektedir $\left(\mathrm{R}^{2}=.493\right)$. Bu bulgudan hareketle bireysel tutum ve davranışlar değişkeni ile yönetsel politikalar değişkeni güçsüzlük düzeyini orta düzeyde anlamlı şekilde etkilemektedir. Başka bir ifade ile güçsüzlük düzeyinde meydana gelen değişimde, yönetsel uygulamalar ve politikalar ile bireysel tutum ve davranışların payı orta düzeydedir. Örgütsel değerler ve normların güçsüzlük düzeyi üzerinde herhangi bir etkisi saptanamamıştır.

Ayrıca varyans analizi sonuçlarının $(\mathrm{F}=118.758, \mathrm{p}<0.01)$ düzeyinde anlamlı olduğu görülmektedir. Varyans analizi sonuçlarının anlamlı olması bağımlı ve bağımsız değişkenler arasındaki ilişkinin doğrusal olduğunu göstermektedir. Yapılan regresyon analizi sonucuna göre, öğretmenlerin bireysel tutum ve davranışlar ile yönetsel uygulamalar ve politikalardan elde ettiği puanlar birlikte ele alındığında, güçsüzlük düzeyine ilişkin toplam varyansın $\% 49^{\prime}$ unu etkilemektedir.

Şekil 1'deki regresyon modeline ilişkin parametreler incelendiğinde her üç değişken birlikte ele alındığında yönetsel uygulamalar ve politikalar ile bireysel tutum ve davranışların güçsüzlügün anlamlı birer yordayıcısı olduğu ancak örgütsel değerler ve normların güçsüzlüğün anlamlı bir yordayıcısı olmadığı görülmektedir.

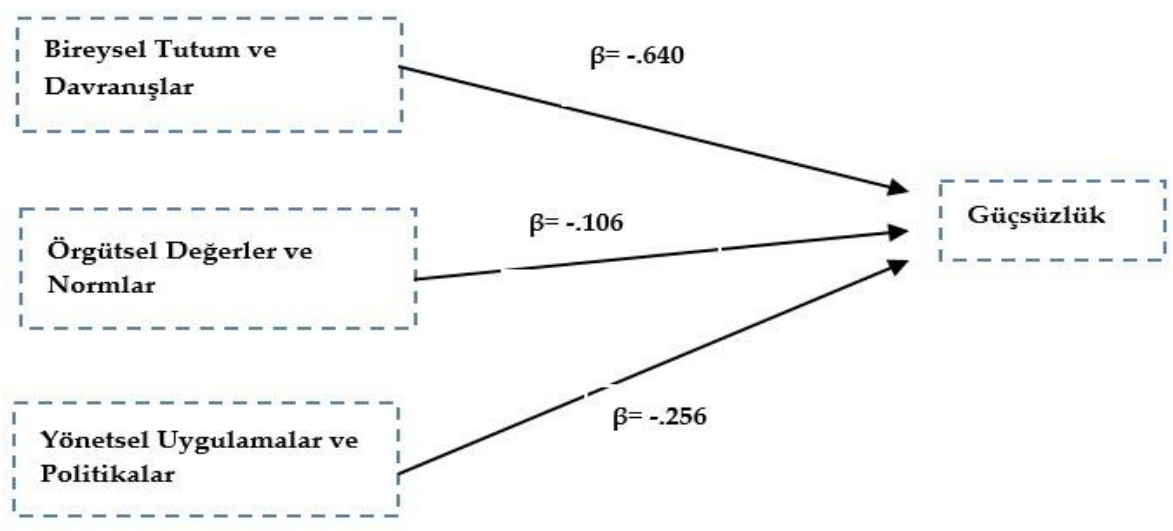

Şekil 1. Güçsüzlük boyutunun yordayıcısı olarak farklılıkların yönetiminin alt boyutları

Tablo XI

Farklllkkların Yönetiminin Boyutlarının Örgütsel Yabancılaşmanın Anlamsızlı Düzeyini Yordamasına İlişkin Regresyon Tablosu

\begin{tabular}{|c|c|c|c|c|c|c|c|}
\hline Bağımlı Değişken & Bağımsız Değişken & $\beta$ & $t$ & p & $\mathbf{F}$ & Model (p) & $\mathbf{R}^{2}$ \\
\hline \multirow{4}{*}{ Anlamsızlik } & Sabit & 42,850 & 25,224 & 00 & \multirow{4}{*}{64,056} & \multirow{4}{*}{00} & \multirow{4}{*}{344} \\
\hline & Bireysel Tutum ve Davranışlar & $-1,127$ & $-6,080$ &, 00 & & & \\
\hline & Örgütsel Değerler ve Normlar & ,222 & 1,686 & ,093 & & & \\
\hline & Yönetsel Uygulamalar ve Politikalar &,- 242 & $-5,437$ & ,00 & & & \\
\hline
\end{tabular}

Tablo XI incelendiğinde; bireysel tutum ve davranışlar, örgütsel değerler ve normlar ile yönetsel uygulamalar ve politikalarının anlamsızlık düzeyini yordamasını sınamak amacıyla uygulanan regresyon modeli istatistiksel olarak anlamlıdır ( $F=64,056 ; p=0.000)$. Bulgulara göre, öğretmenlerin yönetsel uygulamalar 
ve politikalar boyutundaki puanları bir birim arttığında anlamsızlık şeklindeki örgütsel yabancılaşma düzeyinin .24 birim azalmakta ( $B=-0.242 ; t=-5,437 ; p=0.000<0.05)$, öğretmenlerin bireysel tutum ve davranışlar boyutundaki puanları bir birim arttı̆̆ında anlamsızlık biçimindeki örgütsel yabancılaşma .128 birim azalmaktadır $(B=-1,127 ; t=-6,080 ; p=0.000<0.05)$. Öte yandan örgütsel değerler ve normlar boyutunda meydana gelen değişiklikler anlamsızlık düzeyini istatistiksel olarak etkilememektedir $(t=1,686 ; \mathrm{p}=0.093>0.05)$. Bireysel tutum ve davranışlar ile yönetsel uygulamalar ve politikalar değişkenleri birlikte, anlamsızlık düzeyini .34 oranında etkilemektedir $\left(R^{2}=.344\right)$. Bu bulgudan hareketle bireysel tutum ve davranışlar değişkeni ile yönetsel uygulamalar ve politikalar değişkeni anlamsızlık düzeyini orta düzeyde anlamlı şekilde etkilemektedir. Başka bir ifade ile anlamsızlık düzeyinde meydana gelen değişimde, yönetsel uygulamalar ve politikalar ile bireysel tutum ve davranışların payı orta düzeydedir. Örgütsel değerler ve normların anlamsızlık üzerinde herhangi bir etkisi saptanamamıştır.

Ayrıca varyans analizi sonuçlarının ( $\mathrm{F}=64,056 ; \mathrm{p}<0.01)$ düzeyinde anlamlı olduğu görülmektedir. Varyans analizi sonuçlarının anlamlı olması bağımlı ve bağımsız değişkenler arasındaki ilişkinin doğrusal olduğunu göstermektedir. Yapılan regresyon analizi sonucuna göre, öğretmenlerin bireysel tutum ve davranışlar ile yönetsel uygulamalar ve politikalardan elde ettiği puanlar birlikte ele alındığında, anlamsızlık düzeyine ilişkin toplam varyansın \%34'sini etkilemektedir.

Şekil 2'deki regresyon modeline ilişkin parametreler incelendiğinde her üç değişken birlikte ele alındığında yönetsel uygulamalar ve politikalar ile bireysel tutum ve davranışların anlamsızlığın anlamlı birer yordayıcısı olduğu ancak örgütsel değerler ve normların anlamsızlığın anlamlı bir yordayıcısı olmadığı görülmektedir.

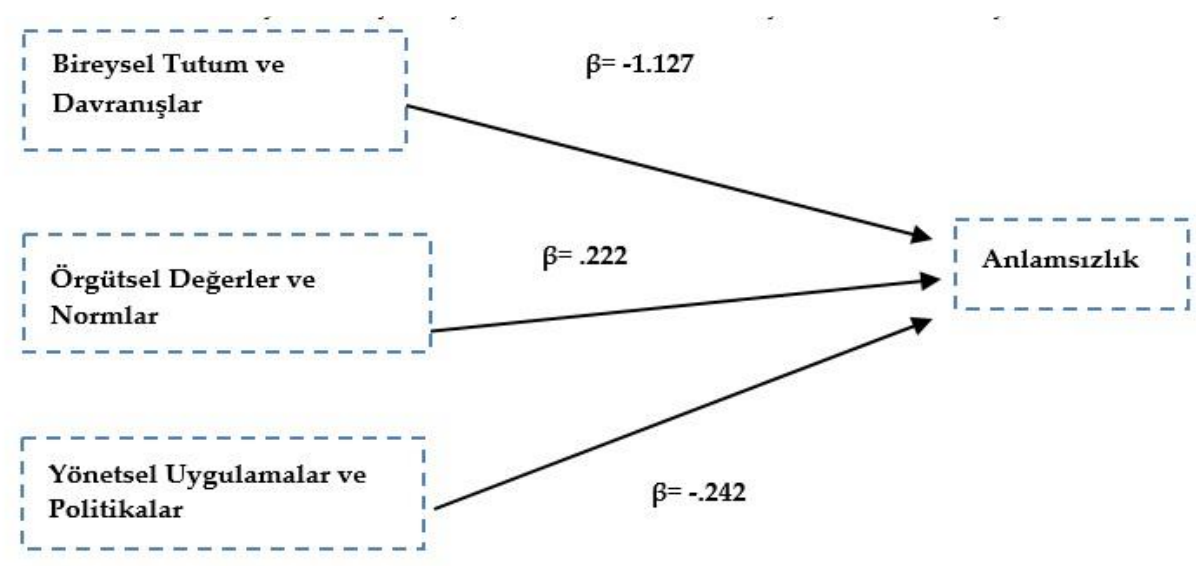

Şekil 2. Anlamsızlık boyutunun yordayıcısı olarak farklılıkların yönetiminin alt boyutları

Tablo XII

Farklılıkların Yönetiminin Boyutlarının Örgütsel Yabancılaşmanın Yalıtılmışlı Düzeyini Yordamasına İlişkin Regresyon Tablosu

\begin{tabular}{|c|c|c|c|c|c|c|c|}
\hline Bağımlı Değişken & Bağımsız Değişken & $\beta$ & $t$ & p & $\mathbf{F}$ & Model (p) & $\mathbf{R}^{2}$ \\
\hline \multirow{4}{*}{ Yalıtılmışlık } & Sabit & 43,815 & 32,198 &, 00 & \multirow{4}{*}{114,536} & \multirow{4}{*}{, 00} & \multirow{4}{*}{484} \\
\hline & Bireysel Tutum ve Davranışlar &,- 958 & $-6,451$ &, 00 & & & \\
\hline & Örgütsel Değerler ve Normlar &,- 175 & $-1,657$ & ,098 & & & \\
\hline & Yönetsel Uygulamalar ve Politikalar &,- 147 & $-4,106$ & , 00 & & & \\
\hline
\end{tabular}

Tablo XII incelendiğinde; bireysel tutum ve davranışlar, örgütsel değerler ve normlar ile yönetsel uygulamalar ve politikalarının yalıtılmışlık düzeyini yordamasını sınamak amacıyla uygulanan regresyon modeli istatistiksel olarak anlamlıdır ( $\mathrm{F}=114,536 ; \mathrm{p}=0.000)$. Bulgulara göre, öğretmenlerin yönetsel uygulamalar ve politikalar boyutundaki puanları bir birim arttığında öğretmenlerin yalıtılmışlık şeklindeki örgütsel yabancılaşma düzeyi .15 birim azalmakta $(ß=-0.147 ; t=-4,106 ; \mathrm{p}=0.000<0.05)$, öğretmenlerin bireysel tutum ve davranışlar boyutundaki puanları bir birim arttığında öğretmenlerin yalıtılmışlık biçimindeki örgütsel yabancılaşma düzeyi .96 birim azalmaktadır ( $(=-958 ; t=-6,451 ; p=0.000<0.05$ ). Öte yandan örgütsel değerler ve normlar boyutunda meydana gelen değişiklikler yalıtılmışlık düzeyini istatistiksel olarak etkilememektedir $(t=-1,657 ; \mathrm{p}=0.098>0.05)$. Bireysel tutum ve davranışlar ile yönetsel uygulamalar ve 
politikalar değişkenleri birlikte, yalıtılmışlık düzeyini .48 oranında etkilemektedir $\left(R^{2}=484\right)$. Bu bulgudan hareketle bireysel tutum ve davranışlar değişkeni ile yönetsel uygulamalar ve politikalar değişkeni yalıtılmışlık düzeyini orta düzeyde anlamlı şekilde etkilemektedir. Başka bir ifade ile yalıtılmışlık düzeyinde meydana gelen değişimde, yönetsel uygulamalar ve politikalar ile bireysel tutum ve davranışların payı orta düzeydedir. Örgütsel değerler ve normların yalıtılmışlık düzeyinin üzerinde herhangi bir etkisi saptanamamıştır.

Ayrıca varyans analizi sonuçlarının ( $\mathrm{F}=114,536 ; \mathrm{p}<0.01)$ düzeyinde anlamlı olduğu görülmektedir. Varyans analizi sonuçlarının anlamlı olması bağımlı ve bağımsız değişkenler arasındaki ilişkinin doğrusal olduğunu göstermektedir. Yapılan regresyon analizi sonucuna göre, öğretmenlerin bireysel tutum ve davranışlar ile yönetsel uygulamalar ve politikalardan elde ettiği puanlar birlikte ele alındığında, yalıtılmışlık düzeyine ilişkin toplam varyansın $\% 48$ 'sini etkilemektedir.

Şekil 3'deki regresyon modeline ilişkin parametreler incelendiğinde her üç değişken birlikte ele alındığında yönetsel uygulamalar ve politikalar ile bireysel tutum ve davranışların yalıtılmışlık düzeyinin anlamlı birer yordayıcısı olduğu ancak örgütsel değerler ve normların yalıtılmışlık düzeyinin anlamlı bir yordayıcısı olmadığı görülmektedir.

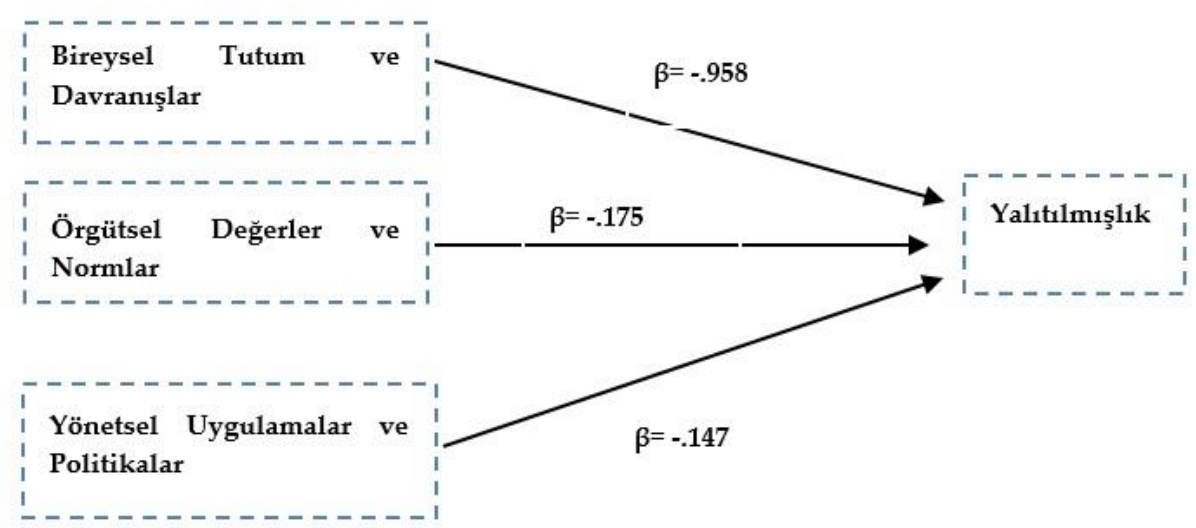

Şekil 3. Yalıtılmışlık boyutunun yordayıcısı olarak farklılıkların yönetiminin alt boyutları

Tablo XIII

Farklılkların Yönetiminin Boyutlarının Örgütsel Yabancılaşmanın Okula Yabancılaşma Düzeyini Yordamasına İlişkin Regresyon Tablosu

\begin{tabular}{|c|c|c|c|c|c|c|c|}
\hline Bağımlı Değişken & Bağımsız Değişken & $\beta$ & $t$ & p & $\mathbf{F}$ & Model (p) & $\mathbf{R}^{2}$ \\
\hline & Sabit & 6,10 & 4,63 & , 00 & \multirow{4}{*}{56,585} & \multirow{4}{*}{,00 } & \multirow{4}{*}{,32 } \\
\hline Okula & Bireysel Tutum ve Davranışlar &,- 634 & $-4,41$ & , 00 & & & \\
\hline \multirow[t]{2}{*}{ Yabancılaşma } & Örgütsel Değerler ve Normlar &,- 072 &,- 71 & 48 & & & \\
\hline & Yönetsel Uygulamalar ve Politikalar & -187 & $-5,4$ & 00 & & & \\
\hline
\end{tabular}

Tablo XIII incelendiğinde; bireysel tutum ve davranışlar, örgütsel değerler ve normlar ile yönetsel uygulamalar ve politikalarının okula yabancılaşma düzeyini, yordamasını sınamak amacıyla uygulanan regresyon modeli istatistiksel olarak anlamlıdır $(\mathrm{F}=56,59 ; \mathrm{p}=0.000)$. Bulgulara göre, öğretmenlerin yönetsel uygulamalar ve politikalar boyutundaki puanları bir birim arttığında öğretmenlerin okula yabancılaşma biçimindeki örgütsel yabancılaşma düzeyi .19 birim azalmakta $(\Theta=-0.187 ; t=-5,4 ; p=0.000<0.05)$, öğretmenlerin bireysel tutum ve davranışlar boyutundaki puanları bir birim arttığında öğretmenlerin okula yabancılaşma şeklindeki örgütsel yabancılaşma düzeyi .63 birim azalmaktadır ( $(=-0.634 ; t=-4,41 ; p=0.000<0.05)$. Öte yandan örgütsel değerler ve normlar boyutunda meydana gelen değişiklikler okula yabancilaşma düzeyini istatistiksel olarak etkilememektedir $(t=-.71 ; \mathrm{p}=0.48>0.05)$. Bireysel tutum ve davranışlar ile yönetsel uygulamalar ve politikalar değişkenleri birlikte, okula yabancılaşma düzeyini .32 oranında etkilemektedir $\left(R^{2}=.32\right)$. Bu bulgudan hareketle bireysel tutum ve davranışlar değişkeni ile yönetsel uygulamalar ve politikalar değişkeni okula yabancılaşma düzeyini orta düzeyde anlamlı şekilde etkilemektedir. Başka bir ifade ile okula yabancılaşma düzeyinde meydana gelen değişimde, yönetsel uygulamalar ve politikalar ile bireysel tutum ve davranışların payı orta düzeydedir. Örgütsel değerler ve normların okula yabancılaşma 
düzeyi üzerinde herhangi bir etkisi saptanamamıştır.

Ayrıca varyans analizi sonuçlarının $(\mathrm{F}=56.585 ; \mathrm{p}<0.01)$ düzeyinde anlamlı olduğu görülmektedir. Varyans analizi sonuçlarının anlamlı olması bağımlı ve bağımsız değişkenler arasındaki ilişkinin doğrusal olduğunu göstermektedir. Yapılan regresyon analizi sonucuna göre, öğretmenlerin bireysel tutum ve davranışlar ile yönetsel uygulamalar ve politikalardan elde ettiği puanlar birlikte ele alındığında, okula yabancılaşma düzeyine ilişkin toplam varyansın \%32'sini etkilemektedir.

Şekil 4'deki regresyon modeline ilişkin parametreler incelendiğinde her üç değişken birlikte ele alındığında yönetsel uygulamalar ve politikalar ile bireysel tutum ve davranışların okula yabancılaşma düzeyinin anlamlı birer yordayıcısı olduğu ancak örgütsel değerler ve normların okula yabancılaşma düzeyinin anlamlı bir yordayıcısı olmadığı görülmektedir.

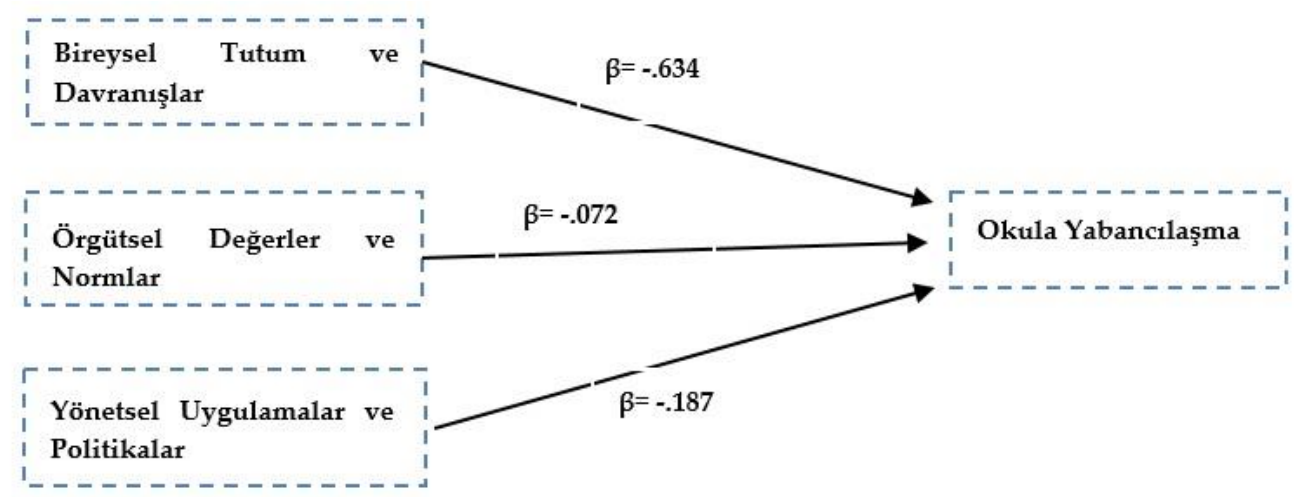

Şekil 4. Okula yabancılaşmanın yordayıcısı olarak farklılıkların yönetiminin alt boyutları

\section{Sonuç ve Tartışma}

Araştırma sonucunda öğretmen algılarına göre farklılıkların yönetimi boyutlarından bireysel tutum ve davranışlar boyutundaki ortalamalarının orta düzeyde, örgütsel değerler ve normlar boyutundaki ortalamalarının orta düzeyde, yönetsel uygulamalar ve politikalar boyutundaki ortalamalarının yüksek düzeyde olduğu görülmekte olup, öğretmenler yönetsel uygulamalarda yöneticilerin farklılıkları iyi yönettiklerini belirtmişlerdir. Memduhoğlu'nun (2007) yaptı̆̆ araştırma sonucunda, yönetici ve öğretmenlerin farklılıkları kabullendikleri, farklılıkları bir zenginlik olarak gördükleri, farklılıkların okullarda bir değer olarak kabullenildiği, yönetici ve öğretmenlerin liselerde yönetimsel uygulamalarda ayrımcıllğın az olduğunu, farklılıkları kabul eden ve değerlendiren bir yönetim anlayışının var olduğunu düşündükleri sonucuna ulaşılmıştır. Bu araştırma sonuçları ile Memduhoğlu'nun (2007) yaptığı araştırma sonuçları benzerlik göstermektedir. Benzer şekilde Keskinkılıç-Kara ve Alabay (2016) ve Memduhoğlu ve Ayyürek (2014) tarafından okul öncesi eğitim kurumlarında yapılan çalışmalarda; Doğan, Uğurlu, Topçu ve Yiğit (2015) tarafından ilk, orta ve lise düzeyinde yapılan çalışmalarda öğretmenlerin, farklılıkların yönetimine ilişkin algıları ortalamanın üstünde bulunmuştur ve araştırmanın bu sonucu ile örtüşmektedir. Ayrıca öğretmenlerin farklılıkların yönetimine ilişkin algılarından en yüksek puanı yönetsel uygulamalar ve politikalar en düşük puanı ise örgütsel değerler ve normlar boyutunda elde ettiği tespit edilmiştir.

Araştırmaya katılan öğretmenlerin güçsüzlük şeklindeki örgütsel yabancılaşma algısının "bazen" düzeyinde, anlamsızlık ve yalıtılmışlık biçimindeki örgütsel yabancılaşma algısının "nadiren" düzeyinde ve okula yabancılaşma şeklindeki örgütsel yabancılaşma algısının "bazen" düzeyinde olduğu saptanmıştır. Zorgül (2014)'ün yaptığı çalışmada da, öğretmenlerin işe yabancılaşmasının okula yabancılaşma boyutunda "bazen" düzeyinde olduğunu belirlenmiştir. Araştırmada ulaşılan sonuçla, bu sonuç örtüşmektedir. Araştırmaya katılan öğretmenlerin görüşlerine göre örgütsel yabancılaşması algısının en düşük düzeyde olduğu boyutun yalıtılmışlık, en yüksek düzeyde olduğu boyutun okula yabancılaşma olduğu belirlenmiştir. Çalışır (2009), Elma (2003), Kasapoğlu (2015) ve Şirin (2009)'nin yaptıkları araştırmaların sonuçlarında da öğretmenlerin işe yabancılaşma düzeylerinin en fazla yaşandığı boyut, okula yabancılaşma boyutudur. Bu sonuçlarla araştırmadan elde edilen sonuç benzerlik göstermektedir. Akpolat ve Oğuz (2015), Erjem (2005), 
Kabaklı-Çimen (2018), ve Yılmaz ile Sarpkaya (2009) tarafından farklı eğitim kademelerinde yapılan araştırmaların sonucunda öğretmenlerin işe yabancılaşma düzeylerinin en fazla yaşandığı boyutun güçsüzlük boyutu olduğu, Şimşek, Balay ve Şimşek (2012)'in yaptığı araştırmanın sonucunda ise öğretmenlerin en fazla yabancılaşma yaşadıkları boyutun kuralsızlık boyutu olduğu ortaya çıkmıştır. Dağlı ve Averbek (2017), Elma (2003), Emir (2012), Erdem (2014), Eryllmaz ve Burgaz (2011) ve Kahveci (2015) tarafindan yapilan araştırmaların sonucunda da öğretmenlerin işe yabancılaşma algılarının "nadiren" düzeyinde yaşadıkları belirlenmiştir. Öğretmenlerin örgütsel yabancılaşma düzeylerinin düşük olmasının nedeni mesleki olarak insanlarla bir arada çalışma, öğretmenler arası informal iletişim, toplum tarafından öğretmenlik mesleğine atfedilen kutsallık, çocuklarla birlikte çalışmanın yarattı̆̆ı doyum ve canlılık olabilir. Ancak düşük düzeyde de olsa yabancılaşmanın varlı̆̆ eğitim örgütlerinde öğretmenlerin işten ayrılmalarına önemli derecede etki eden (Kurtulmuş ve Yiğit, 2016), öğretmenlerin örgütsel sinizm düzeyleri ile ilişkili olan (Akpolat ve Oğuz, 2015) bir kavram olarak karşımıza çıkmakta ve örgüt içinde istenmeyen duygu durumları yaratabilmektedir. $\mathrm{Bu}$ araştırmalar yanında Şimşek, Balay ve Şimşek (2012) sınıf öğretmenlerinin yabancılaşma düzeylerini inceledikleri çalışmalarında öğretmenlerin yabancılaşmalarını "orta" düzey olarak belirlemişlerdir. Bunun nedeni sınıf öğretmenliğinin diğer branş öğretmenliğine göre daha yoğun çalışma gerektiren, veli beklentilerinin daha fazla olduğu bir alan olmasından kaynaklı olabilir. Araştırmanın bu bulgusuyla birlikte, yabancılaşma kavramı ile bütünleşen, Marx'ın belirttiğinin aksine yabancılaşma sadece ekonomik örgütlenme ile değil aynı zamanda belli bir refah düzeyine sahip insanların görev aldığı, sosyal bir sistem olan ve hizmet üreten eğitim örgütlerinde de olabileceği bu çalışma ile ortaya çıkmıştır.

Araştırmaya katılan öğretmenlerin, farklılıkların yönetimine ilişkin algıları ile örgütsel yabancılaşma düzeylerine ilişkin algılarından elde ettikleri puanlara göre, bireysel tutum ve davranışlar ile güçsüzlük, anlamsızlık ve okula yabancılaşma boyutlarında olumsuz yönde "orta" düzeyde, yalıtılmışlık boyutu ile olumsuz yönde "yüksek" düzeyde bir ilişki belirlenmiştir. Örgütsel değerler ve normlar ile okula yabancılaşma ve anlamsızlık arasında olumsuz yönde "orta" düzeyde, yalıtılmışlık ve güçsüzlük ile olumsuz yönde "yüksek" düzeyde bir ilişki olduğu saptanmıştır. Yönetsel uygulamalar ve politikalar boyutu ile okula yabancılaşma, yalıtılmışlık ve anlamsızlık boyutlarında olumsuz yönde "orta" düzeyde, güçsüzlük boyutu ile olumsuz yönde "yüksek" düzeyde bir ilişki olduğu tespit edilmiştir.

Bireysel tutum ve davranışlar, örgütsel değerler ve normlar ile yönetsel uygulamalar ve politikalarının güçsüzlük şeklindeki örgütsel yabancılaşma düzeyini yordamasını sınamak amacıyla uygulan regresyon modeli istatistiksel olarak anlamlı bulunmuştur. Öğretmenlerin, yönetsel uygulamalar ve politikalar boyutundaki puanları bir birim arttı̆̆ında öğretmenlerin güçsüzlük şeklindeki örgütsel yabancılaşma düzeyinin .26 birim azaldığı, öğretmenlerin bireysel tutum ve davranışlar boyutundaki puanları bir birim arttığında öğretmenlerin güçsüzlük biçimindeki örgütsel yabancılaşma düzeyinin .64 birim azaldığı tespit edilmiştir. Öte yandan öğretmenlerin örgütsel değerler ve normlar boyutundaki puanlarındaki değişikliklerin güçsüzlük düzeyini istatistiksel olarak etkilemediği belirlenmiştir. Bireysel tutum ve davranışlar ile yönetsel uygulamalar ve politikalar değişkenleri birlikte, güçsüzlük düzeyini .49 oranında etkilemektedir. Bu sonuçlara göre, bireysel tutum ve davranışlar değişkeni ile yönetsel uygulamalar ve politikalar değişkeninin, güçsüzlük düzeyini "orta" düzeyde anlamlı şekilde etkilediği saptanmıştır. Başka bir ifade ile güçsüzlük düzeyinde meydana gelen değişimde, yönetsel uygulamalar ve politikalar ile bireysel tutum ve davranışların payı "orta" düzeydedir. Örgütsel değerler ve normların güçsüzlük düzeyi üzerinde herhangi bir etkisi saptanmamıştır.

Bireysel tutum ve davranışlar, örgütsel değerler ve normlar ile yönetsel uygulamalar ve politikalarının anlamsızlık şeklindeki örgütsel yabancılaşma düzeyini yordamasını sınamak amacıyla uygulan regresyon modeli istatistiksel olarak anlamlı bulunmuştur. Öğretmenlerin, yönetsel uygulamalar ve politikalar boyutundaki puanları bir birim arttığında, öğretmenlerin anlamsızlık biçimindeki örgütsel yabancılaşma düzeyinin .24 birim azaldığı, öğretmenlerin bireysel tutum ve davranışlar boyutundaki puanları bir birim arttığında, öğretmenlerin anlamsızlık şeklindeki örgütsel yabancılaşma düzeyinin .128 birim azaldığı tespit edilmiştir. Öte yandan öğretmenlerin örgütsel değerler ve normlar boyutundaki puanlarındaki değişikliklerin, anlamsızlık düzeyini istatistiksel olarak etkilemediği saptanmıştır. Bireysel tutum ve davranışlar ile yönetsel uygulamalar ve politikalar değişkenlerinin birlikte, anlamsızlık düzeyini .34 oranında 
etkilediği belirlenmiştir. Bu sonuçlara göre, bireysel tutum ve davranışlar değişkeni ile yönetsel uygulamalar ve politikalar değişkeninin, anlamsızlık düzeyini "orta" düzeyde anlamlı şekilde etkilediği tespit edilmiştir. Başka bir ifade ile anlamsızlık düzeyinde meydana gelen değişimde, yönetsel uygulamalar ve politikalar ile bireysel tutum ve davranışların payı "orta" düzeydedir. Örgütsel değerler ve normların anlamsızlık üzerinde herhangi bir etkisi saptanmamıştır.

Bireysel tutum ve davranışlar, örgütsel değerler ve normlar ile yönetsel uygulamalar ve politikalarının yalıtılmışlık biçimindeki örgütsel yabancılaşma düzeyini yordamasını sınamak amacıyla uygulan regresyon modeli istatistiksel olarak anlamlı bulunmuştur. Öğretmenlerin, yönetsel uygulamalar ve politikalar boyutundaki puanları bir birim arttığında, öğretmenlerin yalıtılmışlık şeklindeki örgütsel yabancılaşma düzeyinin .15 birim azaldığı, öğretmenlerin bireysel tutum ve davranışlar boyutundaki bir birim arttığında, yalıtılmışlık biçimindeki örgütsel yabancılaşma düzeyinin .96 birim azaldığı saptanmıştır. Öte yandan öğretmenlerin örgütsel değerler ve normlar boyutundaki puanlarındaki değişmelerinin, yalıtılmışlık düzeyini istatistiksel olarak etkilemediği tespit edilmiştir. Bireysel tutum ve davranışlar ile yönetsel uygulamalar ve politikalar değişkenlerinin birlikte, yalıtılmışlık düzeyini .48 oranında etkilediği belirlenmiştir. Bu sonuçlara göre, bireysel tutum ve davranışlar değişkeni ile yönetsel uygulamalar ve politikalar değişkeninin, yalıtılmışlık düzeyini "orta" düzeyde anlamlı şekilde etkilediği saptanmıştır. Başka bir ifade ile yalıtılmışlık düzeyinde meydana gelen değişimde, yönetsel uygulamalar ve politikalar ile bireysel tutum ve davranışların payı "orta" düzeydedir. Örgütsel değerler ve normların yalıtılmışlık düzeyinin üzerinde herhangi bir etkisi saptanmamıştır.

Bireysel tutum ve davranışlar, örgütsel değerler ve normlar ile yönetsel uygulamalar ve politikalarının okula yabancılaşma düzeyini, yordamasını sınamak amacıyla uygulan regresyon modeli istatistiksel olarak anlamlı bulunmuştur. Öğretmenlerin, yönetsel uygulamalar ve politikalar boyundaki puanları bir birim arttığında, öğretmenlerin okula yabancılaşma biçimindeki örgütsel yabancılaşma düzeyinin .19 birim azaldığı, öğretmenlerin bireysel tutum ve davranışlar boyutundaki puanları bir birim arttığında, öğretmenlerin okula yabancılaşma şeklindeki örgütsel yabancılaşma düzeyinin .63 birim azaldığı tespit edilmiştir. Öte yandan öğretmenlerin örgütsel değerler ve normlar boyutundaki puanlarında meydana gelen değişikliklerin okula yabancılaşma düzeyini istatistiksel olarak etkilemediği saptanmıştır. Bireysel tutum ve davranışlar ile yönetsel uygulamalar ve politikalar değişkenlerinin birlikte, okula yabancılaşma düzeyini .32 oranında etkilediği belirlenmiştir. Bu sonuçlara göre bireysel tutum ve davranışları değişkeni ile yönetsel uygulamalar ve politikalar değişkeninin, okula yabancılaşma düzeyini "orta" düzeyde anlamlı şekilde etkilediği tespit edilmiştir. Başka bir ifade ile okula yabancılaşma düzeyinde meydana gelen değişimde, yönetsel uygulamalar ve politikalar ile bireysel tutum ve davranışların payı "orta" düzeydedir. Örgütsel değerler ve normların okula yabancılaşma düzeyi üzerinde herhangi bir etkisi saptanamamıştır.

Her üç değişken birlikte ele alındığında yönetsel uygulamalar ve politikalar ile bireysel tutum ve davranışların güçsüzlük, anlamsızlık, yalıtılmışlık ve okula yabancılaşma düzeyinin anlamlı birer yordayıcısı olduğu ancak örgütsel değerler ve normların güçsüzlük, anlamsızlık, yalıtılmışlık ve okula yabancılaşma düzeyinin anlamlı bir yordayıcısı olmadığı belirlenmiştir.

Farklılıkların yönetimine ilişkin algıların yüksek olmasının örgütsel yabancılaşmayı önlediğine ilişkin destekleyici bulgular elde edilmiştir. Çavuş ve diğerleri (2016) tarafından çok kültürlü şirketlerde yapılmış bir araştırmada da farklılıkların yönetiminin çalışanların yabancılaşma düzeyini düşürdügü̈ sonucuna ulaşılmıştır. Bu sonuçtan hareketle farklılıkların yönetiminin öğretmenler, okul yöneticileri ve öğrencilere etkileri üzerine çalışmalar yapılması önemli görünmektedir. Örneğin, okullarda demokratik uygulamalarının artırılması ve ikliminin farklılıkları destekleyici özellikte olması, öğretmenlerin farklılıkları ve birbirlerinin daha iyi tanımasına yardımcı olacak etkinliklerin yapılması, karşılıklı güvenin egemen olduğu bir okul iklimi yaratılması gibi faaliyetlerin yapılması faydalı olacaktır.

Öğretmenlerin görüşlerine göre örgütsel yabancılaşması düzeyinin en yüksek düzeyde olduğu boyutun okula yabancılaşma olduğu belirlenmiştir. Gelecek nesilleri emanet ettiğimiz eğitim sisteminde öğrencilerle sürekli iletişim ve etkileşim içinde olan öğretmenlerin okula yabancılaşmalarının en aza indirilmesi hatta yok 
edilmesi gerekmektedir. Aksi takdirde öğretmenlerin yaşadıkları yabancılaşma doğrudan eğitimin niteliğini olumsuz etkileyecektir. Bu durumu önlemek için okul yöneticileri ve öğretmenler arasındaki ilişkileri iyileştirmek, sorunları en aza indirmek ve öğretmenlerin değerli olarak görülüp örgüte bağlılı̆̆ının artmasını destekleyecek bir okul iklimi oluşturmak, öğretmenlere bazı yetkilerin devredilmesi ve onların örgüt içinde olgun çalışanlar olmalarının sağlanması önem arz etmektedir. Ayrıca demokratik bir anlayış çerçevesinde farklılıkların eksiklik olarak nitelendirilmediği yönetim anlayışının hakim olduğu okullarda, öğretmenlerin sınıf dışı etkinliklerde de görev almaları, kendilerini yalnız ve dışlanmış hissetmemeleri, diğer öğretmenlerle işbirliği içinde mümkün olacaktır. Böylece örgütsel yabancılaşmanın alt boyutlarından olan yalıtılmışlığın en aza indirilmesi sağlanabilir.

Öğretmenlerin nitelikli öğrenme yaşantıları oluşturup oluşturmamaları yabancılaşma yaşayıp yaşamamasıyla yakından ilgilidir. Yabancılaşma yaşayan öğretmen kendisini okul içerisinde yalnız, güçsüz ve anlamsız hissedeceği için hem yönetsel hem de öğretimsel işlerini aksatabilecektir. Bu durum zamanla kendisine ve eğitim sistemine zarar verecektir. Bunun önüne geçmenin yollarından birinin okullarda farklılıkları etkili şekilde yönetmek olduğu bu araştırma ile ortaya çıkmıştır. Farklılıkların yönetimine duyarlı olmayı hedefleyen ve bu doğrultuda bazı politika ve uygulamalar geliştiren okul yöneticileri, öğretmenlerin yabancılaşmasını engelleyebilirler. Okul yöneticilerinden bunun bilincinde olarak hareket etmeleri beklenir.

Örgütsel yabancılaşmayı doğrudan etkileyen yapısal özelliklerin yanında yöneticilerin liderlik stilleri de oldukça etkilidir (Sarros ve diğerleri, 2002). Dolayısıyla okul yöneticileri okullarını amaca yöneltirken öğretmenleri sadece yönetilecek insan kaynakları olarak değil, liderlik edilecek değerler olarak görmeleri günümüz yönetim anlayışı ile daha uyumlu olacaktır. Bu noktada okul yöneticilerinin atanması ve yetiştirilmesi sürecinde politika yapıcıların ve Milli Eğitim Bakanlığı yöneticilerinin lider okul yöneticileri yetiştirme çabası içinde olmaları önem arz etmektedir.

$\mathrm{Bu}$ araştırmanın problemini yanıtını bulma sürecinde yordayıcı ilişkisel tarama deseninden yararlanılmıştır. Örgütsel yabancılaşmanın neden ve sonuçlarını etkili biçimde ortaya koyabilmek için eğitim sisteminin değişik alan ve kademelerinde görev yapan eğitim işgörenlerini kapsayacak biçimde daha geniş boyutlu ve farklı desenlerde araştırmalar yapılarak örgütsel yabancılaşmanın nedenleri derinlemesine incelenebilir.

\section{Kaynaklar}

Aiken, M. ve Hage, J. (1966). Organizational alienation: A comparative analysis. American Sociological Review,31, 497-507.

Akar, H. (2018). The relationships between quality of work life, school alienation, burnout, affective commitment and organizational citizenship: A study on teachers. European Journal of Educational Research, 7(2), 169-180. doi: 10.12973/eu-jer.7.2.169

Akpolat, T. ve Oğuz, E. (2015). İlkokul ve ortaokul öğretmenlerinde örgütsel sinizmin işe yabancilaşma düzeyine etkisi. Mersin Üniversitesi Fakültesi Dergisi, 11(3), 947-971.

Balay, R. ve Sağlam, M. (2004). Eğitimde Farklılıklar Yönetimi Ölçeğinin uygulanabilirliği. Süleyman Demirel Üniversitesi Burdur Eğitim Fakültesi Dergisi, 5(8), 32-46.

Balcı, A. (2010). Sosyal bilimlerde araştırma: Yöntem, teknikler ve ilkeler (8. bs.). Ankara: Pegem Akademi Yayınları.

Barutçugil, İ. (2004). Stratejik insan kaynakları yönetimi (2. bs.). İstanbul: Kariyer Yayınları.

Başaran, İ. E. (2000). Örgütsel Davranış (3. bs.). Ankara: Feryal Matbaası.

Celep, B. (2008). İlköğretim okulu öğretmenlerinin işe yabancılaşması (Kocaeli ili örneği) (Yüksek lisans tezi). Kocaeli Üniversitesi, Sosyal Bilimler Enstitüsü, Kocaeli.

Çako, G. (2012). İlköğretim okullarında öğretmenlerin algılarına göre yöneticilerin farklılıkları yönetimi becerileri ile değişime dirençleri arasındaki ilişki (Yüksek lisans tezi). Trakya Üniversitesi, Edirne. 
Çalışır, İ. (2006). Illköğretim okulu öğretmenlerinin işe yabancılaşması (Bolu ili örneği) (Yüksek Lisans Tezi). Abant İzzet Baysal Üniversitesi, Sosyal Bilimler Enstitüsü, Bolu.

Çalışkan, Ö. (2015). Illköğretim öğrencilerinde teknoloji kullanımı eksenli yabancılaşma: Düzce merkez ilçe örneği (Yüksek lisans tezi). Dumlupınar Üniversitesi, Sosyal Bilimler Enstitüsü, Kütahya.

Çavuş, M. F., Kapusuz, A. G. ve Biçer, M. (2016). Perceptions of diversity management and alienation in multinational companies. Journal of Academic Research in Economics, 8(2), 252-268.

Dağll, A. ve Averbek, E. (2017). The relationship between the organizational alienation and the organizational citizenship behaviors of primary school teachers. Universal Journal of Educational Research, 5(10), 1707-1717.

Demirer, T. ve Özbudun, S. (1998). Yabancılaşma (1. bs). Ankara: Ütopya Yayınevi

Doğan, S., Uğurlu, C. T., Topçu, İ. ve Yiğit, Y. (2015). Farklılıkların yönetimi ile öğrenen okul arasındaki ilişkinin öğretmen algılarına göre incelenmesi. Kırşehir Ĕ̆itim Fakültesi Dergisi, 16 (2), 121-140

Durcan, N.M. (2007). Yabancılaşmanın insan kaynakları yönetimi açısından incelenmesi (Yüksek lisans tezi). Dokuz Eylül Üniversitesi, Sosyal Bilimler Enstitüsü, İzmir.

Elma, C. (2003). Illköğretim okulu öğretmenlerinin işe yabancılaşması (Doktora tezi). Ankara Üniversitesi, Eğitim Bilimleri Enstitüsü, Ankara.

Emir, S. (2012). Ortaöğretim öğretmenlerinin yabancılaşma düzeyleri (Aydın ili örneği) (Yüksek lisans tezi). Adnan Menderes Üniversitesi, Sosyal Bilimler Enstitüsü, Aydın.

Erdem, M. (2014). İş yaşamı kalitesinin işe yabancılaşmayı yordama düzeyi. Kuram ve Uygulamada Eğitim Bilimleri, 14(2), 519-544.

Erjem, Y. (2005). Eğitimde yabancılaşma olgusu ve öğretmen: Lise öğretmenleri üzerine sosyolojik bir araştırma. Türk Ĕ̆itim Bilimleri Dergisi, 3(4), 395-417.

Eryılmaz, A. ve Burgaz, B. (2011). Özel ve resmi lise öğretmenlerinin örgütsel yabancılaşma düzeyleri. Eğitim ve Bilim, 36(161), 271-286.

Fromm, E. (2014). Marx'ın insan anlayışı (1. bs.). (K. Ökten, Çev.). İstanbul: Say Yayınları.

Gökçen, A. ve Çavuş, M. F. (2014). Farklılık yönetimiyle örgütlerde yabancılaşmanın önlenmesi: Yazınsal derleme. Akademik Sosyal Araştırmalar Dergisi, (1), 525-533.

Kabaklı-Çimen, L. (2018). Okul öncesi öğretmenlerinin mesleğe yabancılaşma düzeylerinin bazı değişkenler açısından incelenmesi. Kalem Eğitim ve İnsan Bilimleri Dergisi, 8(2), 519-552.

Kahveci, G. (2015). Okullarda örgüt kültürü, örgütsel güven, örgütsel yabancllaşma ve örgütsel sinisizm arasindaki ilişkiler (Doktora tezi). Fırat Üniversitesi, Eğitim Bilimleri Enstitüsü, Elazı̆̆.

Karasar, N. (2011). Bilimsel araştırma yöntemi: Kavramlar ilkeler teknikler (1. bs.) Ankara: Nobel Akademik Yayıncilik.

Kasapoğlu, S. (2015). İşe yabancılaşma düzeyleri ile örgütsel adalet algıları arasındaki ilişki (Yüksek lisans tezi). Yıldız Teknik Üniversitesi, Sosyal Bilimler Enstitüsü, İstanbul.

Keskinkılıç-Kara, S. B. ve Alabay, E. (2016). Okul öncesi öğretmenlerinin farklılıkların yönetimine ilişkin alg1ları. Hitit Üniversitesi Sosyal Bilimler Enstitüsü Dergisi, 9 (2), 721-742.

Kurtulmuş, M. ve Yiğit, B. (2016). İşe yabancılaşmanın öğretmenlerin işten ayrılma niyetine etkisi. Mersin Üniversitesi Ĕ̆itim Fakültesi Dergisi, 12(3), 860-871.

LeCompte, M.D. ve Dworkin, A.G. (1991). Giving up on School: Student drapouts and teacher burnouts. Newbury Park, California, Corwin Press Inc.

Marx, K. (1993). 1844 el yazmaları (K. Somer, Çev.) (2. bs.). İstanbul: Sol Yayınları. 
Marx, K. (2013). Yabancılaşma (4. bs.). (K. Somer, A. Kardam, S. Belli, A. Gelen, Y. Fincancı ve A. Bilgi, Çev.) Ankara: Sol Yayınları.

Mazur, B. (2010). Cultural diversity in organisational theory and practice. Journal of Intercultural Management, $2(2), 5-15$.

Memduhoğlu, H. B. (2007). Yönetici ve öğretmen görüşlerine göre Türkiye'de kamu liselerinde farklllkların yönetimi (Doktora tezi). Ankara Üniversitesi, Eğitim Bilimleri Enstitüsü, Ankara.

Memduhoğlu, H. B. ve Ayyürek, O. (2014). Öğretmenlerin ve okul yöneticilerinin görüşlerine göre anaokullarında farklılıkların yönetimi. Eğitim Bilimleri Araştırmaları Dergisi, 4 (1), 175-188.

Minaslı, A. V. (2012). Örgüt kültürü ve örgütsel yabancılaşma arasındaki ilişki: Konuyla ilgili bir araştırma (Yüksek lisans tezi). Trakya Üniversitesi, Sosyal Bilimler Enstitüsü, Edirne.

Ofluoğlu, G. ve Büyükyılmaz, O. (2008). Yabancılaşmanın teorik gelişimi ve tarihsel süreç içinde farklı alanlarda görünümleri. Кamu İş Sendikası Dergisi, 10 (1), 113-144.

Okat, B. (2010). Örgütlerde farklllikların yönetimi ve farklılık iklimine kuramsal bir yaklaşım (Yüksek lisans tezi). Dokuz Eylül Üniversitesi, Sosyal Bilimler Enstitüsü, İzmir.

Sarros, J. C., Tanewski, G. A., Winter, R. P., Santora, J. C. ve Densten, I. L. (2002). Work alienation and organizational leadership. British Journal of Management, 13(4), 285-304.

Seeman, M. (1983). Alienation motifs in contemporary theorizing: The hidden continuity of the classic themes. Social Psychology Quarterly, 46(3), 171-184.

Sürgevil, O. (2008). Farklılık ve işgücü farklılıklarının yönetimine analitik bir yaklaşım (Doktora tezi). Dokuz Eylül Üniversitesi, Sosyal Bilimler Enstitüsü, İzmir

Sürgevil, O. (2010). Çalı̧̧ma yaşamında farklılıkların yönetimi (1. bs.). Ankara: Nobel Yayınları.

Sürgevil, O. ve Budak, G. (2008). İşletmelerin farklılıkların yönetimi anlayışına yaklaşım tarzlarının saptanmasına yönelik bir araştırma. Dokuz Eylül Üniversitesi Sosyal Bilimler Enstitüsü Dergisi, 10 (4), 65-96.

Şimşek, H., Balay, R. ve Şimşek, A.S. (2012). İlköğretim sınıf öğretmenlerinde mesleki yabancılaşma. Ĕ̆itim Bilimleri Araştırma Dergisi, 2 (1), 53-72.

Şimşek, M. Ş, Çelik, A., Akgemci T. ve Fettahlığlu, T. (2006). Örgütlerde yabancılaşmanın yönetimi araştırması. Selçuk Üniversitesi Sosyal Bilimler Enstitüsü Dergisi, 15, 569- 587.

Şirin, E. F. (2009). Beden eğitimi öğretmenlerinin işe yabancılaşma düzeylerinin bazı değişkenler açısından incelenmesi. Celal Bayar Üniversitesi Beden Eğitimi ve Spor Bilimleri Dergisi, 4 (4), 164-177.

Tanrıverdi, H. ve Kılıç, N. (2016). Algılanan örgütsel destek ve örgütsel yabancılaşma arasındaki ilişkinin incelenmesi. Hacettepe Üniversitesi Sosyolojik Araştırmalar E-Dergisi, 1(1), 1-18.

Tolan, B. (1981). Çağdaş toplumun bunalımı anomi ve yabancılaşma. Ankara: Ankara İktisadi ve Ticari İlimler Akademisi. No:166.

Tolan, B. (1996). Toplum Bilimlerine Giriş (4. bs.). Ankara: Murat ve Adım Yayınları.

Tolan, B. (2005). Sosyoloji (1. bs.). Ankara: Gazi Kitabevi.

Türk Dil Kurumu (2018). http://www.tdk.gov.tr/ 15 Mayıs 2018 tarihinde adresinden erişildi.

Yılmaz, S. ve Sarpkaya, P. (2009). Eğitim örgütlerinde yabancılaşma ve yönetimi. Uluslararası İnsan Bilimleri Dergisi, 6 (2), 314-333.

Zorgül, G. G. (2014) Illkokul öğretmenlerinin maruz kaldığı psikolojik yıldırma ile işe yabancılaşma arasındaki ilişki (İstanbul ili Avcılar ilçesi örneği) (Yüksek lisans tezi). Bahçeşehir Üniversitesi, Eğitim Bilimleri Enstitüsü, İstanbul. 


\section{EXTENDED ABSTRACT}

\section{Introduction}

Individual differences that exist in all areas of life appear to be a very important phenomenon in terms of organization life. Because, the harmony and harmony among employees of the organization is highly effective in terms of organizational outputs (Sürgevil and Budak, 2008). Diversity management, by adopting the acceptance of human differences as a form of management in organizations as a basic principle of no privilege to any person and group; It aims to make use of all the diversity for the realization of individual and organizational goals (Memduhoğlu, 2007).

Alienation is the separation of the individual from human being. The fact that an individual separated from being a human is to get away from each other and to break up from one another as a result of the loss of human values (Yılmaz and Sarpkaya, 2009).

There are direct relationships between the management of the employees, the managerial policies to be implemented and the way the organization understands and manages alienation. The unfavorable conditions caused by alienation affect the employees. Therefore, unintended consequences may occur in organizational life (Durcan, 2007).

When the literature on diversity management and alienation are examined, it seems that these concepts were not discussed together in terms of educational organizations. Based on the assumption that the management of differences influenced organizational alienation in educational organizations, it was aimed to reveal the perceptions of teachers about the relationship between diversity management and organizational alienation and the answer of the question; is the diversity management the predictor of organizational alienation?

In the light of the answers of the teachers who participated in this research, the following sub-questions were sought;

1. What is their opinion about the diversity management?

2. What is the level of organizational alienation of teachers?

3. Is there a significant relationship between the diversity management and organizational alienation?

4. Is the diversity management predictor of organizational alienation?

\section{Method}

The research is designed with correlational survey model. Diversity managent is the independent variable and organizational alienation is the dependent variable of the research. The population of the study consisted of 3521 teachers working for the public schools in Sultangazi district in Istanbul. The sample of the study consisted of 371 teachers. Both the type of the school and the size of the school were taken into consideration in the determination of the sample. The schools in Sultangazi district are divided into three levels according to their size as large, small and medium sized schools according to stratified sampling technique. Depending on the school type, data were collected from 9 primary schools, 17 secondary schools and 6 high schools, 5 of them were small-scale schools according to the size of the school, 20 of them were medium-sized schools and 7 of them were large-scale schools.

The data were collected by Diversity Management Scale developed by Balay and Sağlam (2004) and by Work Alienation Scale developed by Elma (2003). Percentage, frequency, arithmetic mean and standard deviation were used to determine the views of teachers regarding the diversity management and

organizational alienation. Pearson correlation test was applied to determine the relationship between the diversity management and organizational alienation. Regression analysis technique was used in order to find out whether the diversity management is the predictor of organizational alienation or not. 


\section{Results}

As a result of the study it was determined that the teachers strongly agree with the item "Teachers support their colleagues' efforts to improve their knowledge and skills." in the diversity management scale. It was also found that the teachers got the highest score in terms of managerial practices and policies, and the lowest score in the dimensions of organizational values and norms.

Teachers' perceptions of organizational alienation were rarely at the level of weakness $(X=2,75)$ and alienation of school $(X=3,087)$, sometimes at the level of insignificance $(X=2,00)$, and rarely $(X=1,987)$. In addition, according to the teachers' views, the dimension where organizational alienation is at the lowest level is the alienation of the school where the isolation is at the highest level.

According to the correlation analysis, it is revealed that there is a negative correlation between the dimension of individual attitudes and behaviors of the diversity managenet scale, and the level of weakness, meaninglessness and alienation of the school was found to be negatively correlated with the insignificance dimension of the organizational alienation scale.

Multiple regression analysis was applied to determine how teachers' perceptions of diversity management explain the level of organizational alienation of teachers. Individual attitudes and behaviors as well as managerial practices and policies impact the level of powerlessness by $49 \%\left(\mathrm{R}^{2}=.493\right)$. Organizational values and norms were found to have no impact on the level of weakness.

Individual attitudes and behaviors as well as managerial practices and policies impact the level of meaninglessness by $.34\left(\mathrm{R}^{2}=.344\right)$. Organizational values and norms were found to have no impact on meaninglessness .

Individual attitudes and behaviors as well as managerial practices and policies impact the level of isolation at $48 \%\left(\mathrm{R}^{2}=.484\right)$. Organizational values and norms were found to have no impact on the level of isolation.

Individual attitudes and behaviors as well as managerial practices and policy variables impact school alienation level by $32 \%\left(\mathrm{R}^{2}=.32\right)$. It was found that organizational values and norms had no impact on school alienation level.

\section{Conclusion}

According to the views of the teachers, it was found that, the average of the diversity management in the dimensions of individual attitudes and behaviors, and organizational values and norms were at a moderate level, and the average of the managerial practices and policies were at a high level. In addition, it was found that, teachers' highest perceptions about diversity management were achieved by managerial practices and policies, and their lowest perceptions about diversity management were achieved by organizational values and norms.

At the level of the perception of organizational alienation in the form of weakness and alienation of the teachers, it was found that the perception of organizational alienation in the form of meaninglessness and isolation was seldom. According to the opinions of the teachers participated in the study, it was determined that the dimension where the perception of organizational alienation is at the lowest level is the isolation, where it is at the highest level is the alienation of the school.

According to the teachers' perceptions of diversity management and their perceptions of organizational alienation levels, a high level of negative correlation was found between individual attitudes and behaviors, weakness, meaninglessness, and alienation in school. It was found that there was a high level of negative correlation with organizational values and norms, alienation with school, and meaninglessness, and with a negative level in isolation. It has been determined that there is a high level of negative relationship with the dimension of administrative practices and policies and negatively in the dimensions of alienation, isolation and nonsense. 


\section{Ali ÇELİK \& Sultan Bilge KESKINKILIÇ KARA}

When all three variables were considered together, it was found that managerial practices and policies and individual attitudes and behaviors were significant predictors of weakness, meaninglessness, isolation, and alienation level of school. 